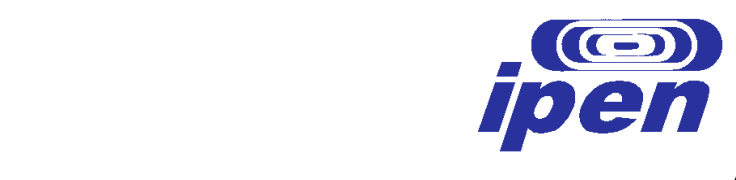

INSTITUTO DE PESQUISAS ENERGÉTICAS E NUCLEARES

Autarquia associada à Universidade de São Paulo

\title{
CARACTERIZAÇÃO MICROESTRUTURAL, MECÂNICA E TRATAMENTO TÉRMICO DA LIGA AA-6082 OBTIDA PELO PROCESSO DE CONFORMAÇÃO POR SPRAY
}

GONÇALO SIQUEIRA

Dissertação apresentada como parte dos requisitos para obtenção do Grau de Mestre em Ciências na Área de Tecnologia Nuclear - Materiais.

Orientador:

Dr. Jesualdo Luiz Rossi

SÃO PAULO

2010 


\section{$((-))$ \\ ipen \\ INSTITUTO DE PESQUISAS ENERGÉTICAS E NUCLEARES}

Autarquia associada à Universidade de São Paulo

\section{CARACTERIZAÇÃO MICROESTRUTURAL, MECÂNICA E TRATAMENTO TÉRMICO DA LIGA AA-6082 OBTIDA PELO PROCESSO DE CONFORMAÇÃO POR SPRAY}

GONÇALO SIQUEIRA

Dissertação apresentada como parte dos requisitos para obtenção do Grau de Mestre em Ciências na Área de Tecnologia Nuclear - Materiais.

Orientador:

Dr. Jesualdo Luiz Rossi

SÃO PAULO

2010 
Dedico este trabalho á minha mãe Elena Siqueira pelo seu carinho, amor, dedicação, e ensinamentos da vida presente com DEUS. 
"Se fiz descobertas valiosas, foi mais por ter paciência do que qualquer outro talento."

Isaac Newton 


\section{AGRADECIMENTOS}

Primeiramente a Deus pela presença constante nas nossas vidas.

Ao meu orientador Dr. Jesualdo Luiz Rossi pelo apoio e dedicação nos trabalhos, com seus valiosos conselhos acadêmicos e pelas contribuições sempre relevantes.

Ao Dr. Edilson Rosa Barbosa de Jesus pelas discussões construtivas durante a execução do trabalho.

Ao Dr. Edson Souza de Jesus Filho pelas informações e orientações para o aprimoramento deste trabalho.

Ao Dr. Cristiano Stefano Mucsi pelas informações valiosas na redação de trabalhos para congressos.

Á Profa. Dra. Isolda Costa pelo auxílio constante e disponibilização do Laboratório de Corrosão.

Ao Dr. Hidetoshi Takiishi e equipe pela disponibilização de laboratórios.

Aos técnicos Glauson Aparecido F. Machado, Dileusa Alves da Silva Galissi pela colaboração nos laboratórios de metalografia.

Ás secretárias do CCTM Marlene M. Marcelino e Elizabete dos Santos pelo apoio constante.

Á Escola Politécnica da Universidade de São Paulo pelo apoio constante do Dr. Hélio Wiebeck.

A Faculdade de Tecnologia de São Bernardo do Campo e ao Diretor desta unidade Prof. Rômulo Albuquerque, ao coordenador Prof. Edmilson Souza Carvalho, a Coordenadora Profa. Dra. Anna Cristina Barbosa, ao coordenador Prof. Marcos Zamboni, ao Prof. Me. Erasmo Assumpção Filho, a Profa. Me. Samaris Ramiro Pereira, a Profa. Me. Lígia Pereira, a Profa. Me. Nanci Bolognese, ao Prof. Dr. Paulo Roberto Schroeder de Souza pelo apoio e incentivo.

A Profa. Me. Marlene Salete Uberti da Universidade Federal Rural do Rio de Janeiro por sua colaboração e incentivo no mestrado.

A Profa. Dra. Juliana da Silva Brandão da Universidade Regional de Blumenau pelo seu incentivo na minha carreira de docente.

Ao consultor Prof. Alexandre Anusauskas pela ajuda na construção das peças 
utilizadas nos dispositivos para tratamento térmico.

A DANNA Engenharia consultoria de treinamentos em especial ao Dr. Mário D'Anna por acreditar em nosso trabalho.

Ao Prof. Dr. Osni Lisboa do CTA-IEAv - Instituto de Estudos Avançados, pelos conselhos acadêmicos no período de graduação.

Á EMAE - Empresa Metropolitana de Águas e Energia pela utilização de suas oficinas no início do trabalho.

Aos amigos do mestrado Eng. Me. Marcos Gonzales Fernandes, a Bacharel em Química Cibele Dmitrijevas pela ajuda, estudos das disciplinas e apoio nos momentos de dificuldades.

Ao amigo Me. Ademilson Rogério pelo apoio e incentivo neste trabalho.

Ao amigo Físico Me. Leandro César Gomes Pereira Safra pelo acompanhamento e apoio constante.

Aos funcionários da ALCOA e ao Eng. Celso Diniz e Hélio Pina pelas micrografias

Aos funcionários da CBA Companhia Brasileira de Alumínio pelo apoio e divulgação deste trabalho.

A meus irmãos Amauri, esposa Geni sobrinhos Eduardo e Amauri Jr., irmão Humberto, cunhada Ângela, sobrinho Franklin e irmã Dulce e esposo Giusepe.

Á minha querida companheira Claudete Olímpio de Abreu pela grandiosa compreensão, presença, incentivo, ajuda constante e carinho especial.

A todos os demais colegas. 


\section{CARACTERIZAÇÃO MICROESTRUTURAL, MECÂNICA E TRATAMENTO TÉRMICO DA LIGA AA-6082 OBTIDA PELO PROCESSO DE CONFORMAÇÃO POR SPRAY}

\section{Gonçalo Siqueira}

\section{RESUMO}

O processo de conformação por spray é interessante devido à capacidade de conjugar, em apenas uma etapa do processo, a vantagem da técnica de solidificação rápida combinada com alta produtividade dos processos de fundição convencional. Este processo permite a obtenção de materiais livre de macrossegregações, livre de porosidades e com microestrutura refinada. A evolução recente das pesquisas está levando ao desenvolvimento de novas ligas e os resultados têm sido interessantes. O processo de solidificação rápida inerente da conformação por spray permite a produção de ligas com composições diferentes das obtidas pela fundição convencional. $O$ objetivo deste trabalho foi o de caracterizar mecanicamente uma liga de alumínio AA-6082 conformada por spray. Os resultados de testes de dureza Vickers são apresentados para seções de um preformado em relação a sua altura (em um arranjo tridimensional). O material foi avaliado na condição como conformado por spray e após tratamento térmico de solubilização a $525 \stackrel{\circ}{\circ}$ por $1 \mathrm{~h}$, seguido por envelhecimento a $125^{\circ} \mathrm{C}$ por períodos distintos de $1 \mathrm{~h}$, $10 \mathrm{~h}, 100 \mathrm{~h}$ e $500 \mathrm{~h}$. É mostrado que o a liga AA 6082 conformada por spray mostra uma boa estabilidade térmica em relação a variação da dureza durante 0 envelhecimento. 


\title{
MICROSTRUCTURAL CHARACTERIZATION, MECHANICAL AND HEAT TREATMENT OF THE SPRAY FORMED AA60-82 ALLOY
}

\section{Gonçalo Siqueira}

\begin{abstract}
The spray forming technology combines in a single step the advantages of the rapid solidification techniques and high the productivity of the conventional casting processes, allowing obtention of preforms with a refined microstructure, almost without porosity and macrosegregation free. The development and research efforts are leading to interesting alloys and materials production. The rapid solidification processes inherent to the spray forming allow the production of alloys with different compositions from those obtained by conventional ingot processes. The aim of this work was to carry out mechanical properties characterization of a spray formed AA6082 alloy. The hardness results are presented in different sections related to the height of the spray formed preform (in a three-dimensional arrangement). The material was evaluated in the as sprayed condition and after heat treatment of solution at $525^{\circ} \mathrm{C}$ for $1 \mathrm{~h}$, and aging for $1 \mathrm{~h}, 10 \mathrm{~h}, 100 \mathrm{~h}$ and $500 \mathrm{~h}$ periods. It was shown that the spray formed AA-6082 aluminum alloy is very stable regarding hardness variation during aging.
\end{abstract}




\section{LISTA DE FIGURAS}

Página

Figura 1. Redução da espessura da chapa pelo método de laminação. 10

Figura 2. Esquema de laminador quádruplo empregado na laminação a frio. 12

Figura 3. Processo de conformação por spray com jato único na direção do substrato [24]. 14

Figura 4. Desenho esquemático do processo Osprey de conformação por spray [19].

Figura 5. Preformado com diâmetro maior denominado base e diâmetro menor lado base nas dimensões.

Figura 6. Visualização do preformado: base (A) e topo (B), em processo de corte. 18

Figura 7. Esquema do corte das amostras situado na base e topo do preformado.

Figura 8. Exemplo típico de indentação de dureza Vickers com carga de 31,25 kgf usada em todo o experimento. 20

Figura 9. Massa térmica com três blocos, termopar anexo no forno carregado com as amostras. As peças do preformado foram partidas em formato de pastilhas para tratamento térmico.

Figura 10. Massa térmica com três blocos e o termopar anexo com forno em operação, na temperatura de $525^{\circ} \mathrm{C}$.

Figura 11. a) Representação do perfil de dureza Vickers para o material do topo na condição como conformado por spray mostrando a variação radial de dureza (região da borda em azul, região do meio em amarelo e região do centro em verde. b) Gráfico de barras mostrando a evolução do perfil em linha para as regiões da borda em azul, região do meio em amarelo e região do centro em verde. c) Superposição do gráfico do perfil de dureza Vickers com a imagem da seção do preformado. .... 25

Figura 12. a) Representação do perfil de dureza Vickers para o material da base na condição como conformado por spray mostrando a variação radial de dureza (região da borda em azul, região do meio em amarelo e região do centro em verde. b) Gráfico de barras mostrando a evolução do perfil em linha para as regiões da borda em azul, região do meio em amarelo e região do centro em verde.

Figura 13. a) Representação do perfil de dureza Vickers para o material da base na condição como conformado por spray mostrando a variação radial de dureza (região da borda em azul, região do meio em amarelo e região do centro em verde. b) Gráfico de barras mostrando a evolução do perfil em linha para as regiões da borda em azul, região do meio em amarelo e região do centro em verde. Tratamento 
térmico de $1 \mathrm{~h}$ de solubilização a $525^{\circ} \mathrm{C}$ sem envelhecimento. Lado base do preformado. .................................................................................................. 26

Figura 14. a) Representação do perfil de dureza Vickers para o material do topo na condição como conformado por spray mostrando a variação radial de dureza (região da borda em azul, região do meio em amarelo e região do centro em verde. b) Gráfico de barras mostrando a evolução do perfil em linha para as regiões do topo em azul, região do meio em amarelo e região do centro em verde. Tratamento térmico de $1 \mathrm{~h}$ solubilização a $525^{\circ} \mathrm{C}$ sem envelhecimento. Lado topo do preformado.

Figura 15. a) Representação do perfil de dureza Vickers para o material da base na condição como conformado por spray mostrando a variação radial de dureza (região da borda em azul, região do meio em amarelo e região do centro em verde. b) Gráfico de barras mostrando a evolução do perfil em linha para as regiões da borda em azul, região do meio em amarelo e região do centro em ver de. Tratamento térmico de $1 \mathrm{~h}$ solubilização a $525^{\circ} \mathrm{C}$ e $1 \mathrm{~h}$ de envelhecimento a $125^{\circ} \mathrm{C}$. Lado base do preformado.

Figura 16. a) Representação do perfil de dureza Vickers para o material do topo na condição como conformado por spray mostrando a variação radial de dureza (região da borda em azul, região do meio em amarelo e região do centro em verde. b) Gráfico de barras mostrando a evolução do perfil em linha para as regiões da borda em azul, região do meio em amarelo e região do centro em verde. Tratamento térmico de $1 \mathrm{~h}$ solubilização a $525^{\circ} \mathrm{C}$ e $1 \mathrm{~h}$ de envelhecimento a $125^{\circ} \mathrm{C}$. Lado topo do preformado.

Figura 17. a) Representação do perfil de dureza Vickers para o material da base na condição como conformado por spray mostrando a variação radial de dureza (região da borda em azul, região do meio em amarelo e região do centro em verde. b) Gráfico de barras mostrando a evolução do perfil em linha para as regiões da borda em azul, região do meio em amarelo e região do centro em verde.Tratamento térmico de $1 \mathrm{~h}$ solubilização a $525^{\circ} \mathrm{C}$ e $10 \mathrm{~h}$ de envelhecimento a $125^{\circ} \mathrm{C}$. Lado base do preformado. 28

Figura 18. a) Representação do perfil de dureza Vickers para o material do topo na condição como conformado por spray mostrando a variação radial de dureza (região da borda em azul, região do meio em amarelo e região do centro em verde. b) Gráfico de barras mostrando a evolução do perfil em linha para as regiões da borda em azul, região do meio em amarelo e região do centro em verde. Tratamento térmico de $1 \mathrm{~h}$ solubilização a $525^{\circ} \mathrm{C}$ e $10 \mathrm{~h}$ de envelhecimento a $125^{\circ} \mathrm{C}$. Lado topo do preformado.

Figura 19. a) Representação do perfil de dureza Vickers para o material da base na condição como conformado por spray mostrando a variação radial de dureza (região da borda em azul, região do meio em amarelo e região do centro em verde. b) Gráfico de barras mostrando a evolução do perfil em linha para as regiões da borda em azul, região do meio em amarelo e região do centro em verde. Tratamento térmico de $1 \mathrm{~h}$ solubilização a $525^{\circ} \mathrm{C}$ e $100 \mathrm{~h}$ de envelhecimento a $125^{\circ} \mathrm{C}$. Lado base do preformado. 
Figura 20. Representação do perfil de dureza Vickers para o material do topo na condição como conformado por spray mostrando a variação radial de dureza (região da borda em azul, região do meio em amarelo e região do centro em verde. b) Gráfico de barras mostrando a evolução do perfil em linha para as regiões da borda em azul, região do meio em amarelo e região do centro em verde. Tratamento térmico de $1 \mathrm{~h}$ solubilização a $525{ }^{\circ} \mathrm{C}$ e $100 \mathrm{~h}$ de envelhecimento a $125{ }^{\circ} \mathrm{C}$. Lado topo do preformado. 30

Figura 21. a) Representação do perfil de dureza Vickers para o material da base na condição como conformado por spray mostrando a variação radial de dureza (região da borda em azul, região do meio em amarelo e região do centro em verde. b) Gráfico de barras mostrando a evolução do perfil em linha para as regiões da borda em azul, região do meio em amarelo e região do centro em verde. Tratamento térmico de $1 \mathrm{~h}$ solubilização a $525{ }^{\circ} \mathrm{C}$ e $500 \mathrm{~h}$ de envelhecimento a $125{ }^{\circ} \mathrm{C}$. Lado base do preformado. 30

Figura 22. a) Representação do perfil de dureza Vickers para o material do topo na condição como conformado por spray mostrando a variação radial de dureza (região da borda em azul, região do meio em amarelo e região do centro em verde. b) Gráfico de barras mostrando a evolução do perfil em linha para as regiões da borda em azul, região do meio em amarelo e região do centro em verde. Tratamento térmico de $1 \mathrm{~h}$ solubilização a $525{ }^{\circ} \mathrm{C}$ e $500 \mathrm{~h}$ de envelhecimento a $125{ }^{\circ} \mathrm{C}$. Lado topo do preformado.

Figura 23. Material de partida. Matéria prima do processo antes da fusão para a conformação por spray.

Figura 24. Material após realização do processo de conformação por spray, sem passar pelas fases do tratamento térmico. Lado base da preformado. 33

Figura 25. Material após realização do processo de conformação por spray, sem passar pelas fases do tratamento térmico. Lado topo da preformado.

Figura 26. Material após realização do processo de conformação por spray. Tratamento térmico de $1 \mathrm{~h}$ de solubilização a $525{ }^{\circ} \mathrm{C}$ sem envelhecimento. Posição 7TC.

Figura 27. Material após realização do processo de conformação por spray. Tratamento térmico $1 \mathrm{~h}$ de solubilização a $525{ }^{\circ} \mathrm{C}$ sem envelhecimento. Posição 17BC.

Figura 28. Material após realização do processo de conformação por spray. Tratamento térmico de $1 \mathrm{~h}$ de solubilização a $525{ }^{\circ} \mathrm{C}$ e $1 \mathrm{~h}$ de envelhecimento a 125 $\stackrel{\circ}{ } \mathrm{C}$.

Figura 29. Material após realização do processo de conformação por spray. Tratamento térmico de $1 \mathrm{~h}$ de solubilização a $525{ }^{\circ} \mathrm{C}$ e $10 \mathrm{~h}$ de envelhecimento a 125 oC. Posição 17TB. 
Figura 30. Material após realização do processo de conformação por spray. Tratamento térmico de $1 \mathrm{~h}$ de solubilização a $525{ }^{\circ} \mathrm{C}$ e $10 \mathrm{~h}$ de envelhecimento a 125 ․ . Lado topo preformado. Posição 7TM. 36

Figura 31. Material após realização do processo de conformação por spray. Tratamento térmico de $1 \mathrm{~h}$ de solubilização a $525{ }^{\circ} \mathrm{C}$ e $100 \mathrm{~h}$ de envelhecimento a $125^{\circ} \mathrm{C}$. Posição 2BB. 36

Figura 32. Material após realização do processo de conformação por spray. Tratamento térmico de $100 \mathrm{~h}$ de solubilização a $525^{\circ} \mathrm{C}$ e $100 \mathrm{~h}$ de envelhecimento a $125^{\circ} \mathrm{C}$. Posição 2BB.

Figura 33. Material após realização do processo de conformação por spray. Tratamento térmico de $1 \mathrm{~h}$ de solubilização a $525{ }^{\circ} \mathrm{C}$ e $500 \mathrm{~h}$ de envelhecimento a $125^{\circ} \mathrm{C}$. Lado base da preformado. Posição 7BC.

Figura 34. Material após realização do processo de conformação por spray. Tratamento térmico de $500 \mathrm{~h}$ de solubilização a $525^{\circ} \mathrm{C}$ e $500 \mathrm{~h}$ de envelhecimento a $125^{\circ} \mathrm{C}$. Posição 8BM. 38 


\section{LISTA DE TABELAS}

Página

TABELA I. Produção brasileira de alumínio primário referente à data de 09/2010. Fonte: ABAL - Associação Brasileira de Alumínio.

TABELA II. Séries de ligas de alumínio e principais aplicações. ............................ 5

TABELA III. Ligas de alumínio trabalháveis. *Adaptação para a liga 6082 ............ 7

TABELA IV. Composição química do material de partida (\% massa), antes da conformação por spray, obtida por espectrofotometria de absorção atômica.

TABELA V. Composição química do material conformado por spray (\% massa) obtida por espectrofotometria de absorção atômica denominado lado superior (topo).

TABELA VI. Composição química do material conformado por spray (\% massa) obtida por espectrofotometria de absorção atômica denominado lado inferior (base). 


\section{SUMÁRIO}

Página

1. INTRODUÇÃO

2. OBJETIVO 3

3. REVISÃO BIBLIOGRÁFICA 4

\begin{tabular}{ll}
\hline 3.1 Alumínio & 4 \\
\hline 3.1 .1 Licas de aluminio
\end{tabular}

3.1.1 Ligas de alumínio 4

3.1.2 Classificação das ligas de alumínio $\quad 5$

3.1.3 Liga AA-6082 8

3.2 Processos na utilização das ligas de alumínio-extrusão 9

3.2.1 Laminação a quente 10

3.2.2 Laminação a frio 11

3.3 Conformação por spray 13

$\begin{array}{ll}\text { 3.3.1 A conformação por spray } & 14\end{array}$

$\begin{array}{ll}\text { 3.3.2 Parâmetros do processo Osprey } & 15\end{array}$

4. PROCEDIMENTO EXPERIMENTAL 17

4.1 Material 17

$\begin{array}{ll}4.2 \text { Métodos } & 17\end{array}$

4.3 Caracterização 17

$\begin{array}{ll}\text { 4.3.1 Material preformado } & 17\end{array}$

4.3.2 Análise química do preformado 19

$\begin{array}{ll}\text { 4.3.3 Microscopia óptica } & 19\end{array}$

4.3.4 Preparação dos corpos-de-prova 20

$\begin{array}{ll}4.3 .5 \text { Lixamento e polimento } & 20\end{array}$

4.3.6 Tratamento térmico 20

5. RESULTADOS E DISCUSSÃO 22

5.1 Composição química 22

5.2 Ensaios de dureza Vickers 23

5.3 Microscopia óptica (MO) 31

6. CONCLUSÕES 39

$\begin{array}{ll}\text { 7. TRABALHOS FUTUROS } & 40\end{array}$

REFERENCIAS BIBLIOGRÁFICAS $\quad 41$ 


\section{INTRODUÇÃO}

A descoberta do alumínio foi realizada por Sir Humphrey Davy em 1809, tendo sido isolado pela primeira vez em 1825 por H. C. Oersted. Porém, apenas em 1886 foi desenvolvido um processo industrial econômico de redução. Neste ano, dois cientistas trabalhando independentemente, Charles Martin Hall, nos Estados Unidos, e Paul (Louis-Toussaint) Héroult, na França, inventaram o mesmo procedimento eletrolítico para reduzir a alumina em alumínio.

A bauxita é o minério mais importante, com um teor de óxido de alumínio entre $35 \%$ a $45 \%$; suas jazidas localizam-se principalmente nas regiões tropicais e, no Brasil concentram-se na área amazônica, detendo a terceira maior reserva de bauxita do mundo. Os estudos, as atividades de pesquisa, desenvolvimentos pelas indústrias do alumínio, pelos laboratórios acadêmicos e pelos seus usuários têm levado a um maior conhecimento das características de engenharia deste metal, além do que técnicas de fabricação, de soldagem e de acabamento têm sido desenvolvidas [1].

O alumínio é terceiro elemento mais abundante na crosta terrestre. Seu processo de produção apresenta-se como o metal mais novo usado em escala industrial. O alumínio começou a ser produzido comercialmente há cerca de 120 anos. Atualmente sua produção ultrapassa a todos os outros metais não-ferrosos. Com isso observa-se sua relevância para a nossa sociedade atual.

Os dois maiores produtores mundiais são Estados Unidos e o Canadá, mas há uma dependência da importação, pois nenhum dos países citados possuem as jazidas de bauxita em sua localidade. O Brasil apresenta-se como terceiro detentor de maior reserva do minério no mundo, com sua localização na região amazônica, ficando somente atrás da Austrália e Guiné. Pode-se encontrar no sudeste do Brasil, no Estado de Minas Gerias nos municípios de Poços de Caldas e Cataguases [1].

O Brasil é um país com um alto potencial de produção do alumínio, pois além de ter uma grande reserva de bauxita possui um grande potencial hidroelétrico. A produção de alumínio no Brasil vem crescendo nos últimos tempos e a Associação Brasileira do Alumínio - ABAL divulgou a produção de alumínio primário de maio de 2010, foram produzidas um total de 130,9 mil toneladas de alumínio primário, o que representando um aumento de 1,4\% em relação ao mesmo mês do ano de 2009. Verificando-se no acumulado janeiro- 
maio, o setor teve a produção de 634,6 mil toneladas, volume 1,6 \% menor que o produzido no mesmo período anterior. Totalizando-se um volume produzido com crescimento de $1,4 \%$ em relação a maio de 2009 como pode ser observado na TAB. 1.

TABELA I. Produção brasileira de alumínio primário referente à data de 09/2010. Fonte: ABAL - Associação Brasileira de Alumínio.

\begin{tabular}{|c|c|c|c|c|c|c|c|}
\hline \multicolumn{2}{|l|}{ Empresas } & \multicolumn{2}{|c|}{2009} & \multicolumn{2}{|c|}{2010} & \multicolumn{2}{|c|}{$\begin{array}{c}\text { Variação 2010/2009 } \\
(\%)\end{array}$} \\
\hline & & Junho & Jan-Jun & Junho & Jan-Jun & Junho & Jan-Jun \\
\hline Albras & $(\mathrm{PA})$ & 37,3 & 226,6 & 37,4 & 221,6 & 0,3 & $-2,2$ \\
\hline $\begin{array}{l}\text { Alcoa } \\
\text { Poços de Caldas } \\
\text { São Luís }\end{array}$ & $\begin{array}{l}\text { (MG) } \\
\text { (MA) }\end{array}$ & $\begin{array}{r}26,8 \\
5,3 \\
21,5 \\
\end{array}$ & $\begin{array}{r}162,4 \\
33,0 \\
129,4 \\
\end{array}$ & $\begin{array}{r}28,7 \\
7,5 \\
21,2 \\
\end{array}$ & $\begin{array}{r}172,0 \\
41,6 \\
130,4 \\
\end{array}$ & $\begin{array}{r}7,1 \\
41,5 \\
-1,4 \\
\end{array}$ & $\begin{array}{r}5,9 \\
26,1 \\
0,8 \\
\end{array}$ \\
\hline BHP Billiton & (MA) & 14,3 & 86,1 & 14,1 & 85,6 & $-1,4$ & $-0,6$ \\
\hline CBA & $(\mathrm{SP})$ & 39,0 & 233,6 & 39,0 & 235,2 & 0,0 & 0,7 \\
\hline $\begin{array}{l}\text { Novelis } \\
\text { Ouro Preto } \\
\text { Aratu }\end{array}$ & $\begin{array}{l}\text { (MG) } \\
(\mathrm{BA}) \\
\end{array}$ & $\begin{array}{l}8,2 \\
3,9 \\
4,3 \\
\end{array}$ & $\begin{array}{l}50,7 \\
23,8 \\
26,9 \\
\end{array}$ & $\begin{array}{l}7,4 \\
4,0 \\
3,4 \\
\end{array}$ & $\begin{array}{l}46,8 \\
24,1 \\
22,7 \\
\end{array}$ & $\begin{array}{r}-9,8 \\
2,6 \\
-20,9 \\
\end{array}$ & $\begin{array}{r}-7,7 \\
1,3 \\
-15,6 \\
\end{array}$ \\
\hline Valesul & (RJ) & 0,0 & 10,2 & 0,0 & 0,0 & 0,0 & $-100,0$ \\
\hline Total & & 125,6 & 769,6 & 126,6 & 761,2 & 0,8 & $-1,1$ \\
\hline
\end{tabular}

Fonte: Produtores Primários 


\section{OBJETIVO}

O objetivo deste trabalho foi o de realizar a caracterização microestrutural e mecânica da liga AA-6082 conformada por spray. Para tanto, executou-se medidas de dureza Vickers em pontos distintos de duas seções de um preformado nas condições como conformado por spray e após tratamento térmicos de solubilização a $525 \stackrel{\circ}{\circ} \mathrm{C}$ por $1 \mathrm{~h}$ seguido de envelhecimento por períodos de $1 \mathrm{~h}, 10 \mathrm{~h}, 100 \mathrm{~h}$ e $500 \mathrm{~h}$ a $125^{\circ} \mathrm{C}$. 


\section{REVISÃO BIBLIOGRÁFICA}

\subsection{Alumínio}

O alumínio é um metal que possui baixa massa específica $\left(2,75 \mathrm{~g} / \mathrm{cm}^{3}\right.$ para o alumínio puro) que possui estrutura cristalina CFC - cúbica de face centrada e em combinação com o magnésio faz parte do grupo denominado ligas leves [1]. $O$ alumínio possui excelente propriedades físico-químicas considerando a baixa massa específica, a resistência à corrosão, a alta condutibilidade térmica e elétrica e apresentam-se infinitas reciclagens com uma gama variável na utilização, que o torna o metal não-ferroso de maior consumo anual. $O$ alumínio se apresenta com ductilidade e tenacidade elevadas a baixas temperaturas que é uma característica muito importante [2]. O alumínio é o metal mais abundante na crosta terrestre, porém o seu processamento é caro, tendo restringido a sua aplicação até meados do século XIX. Os processos de produção do alumínio primário alavancou-se comercialmente somente em $1886 \mathrm{com}$ o surgimento do método Hall-Héroult [3]. Neste processo, a bauxita é refinada para produção da alumina através de um banho de criolita e sais fluoretos, que tem como objetivo controlar a temperatura, densidade e resistividade do banho e a solubilidade da alumina. O metal é coletado em cadinhos onde são encaminhados para fundição para ser refundidos ou transformados em lingotes. O metal obtido nesse processo contém uma grande quantidade de impurezas, para se obter um índice de pureza maior, outros métodos de refino são empregados [3]. O alumínio secundário é produzido a partir da reciclagem de sucatas e é muito valorizado, pois apresenta uma grande economia de energia elétrica [4].

Hoje é um dos materiais mais usado atualmente e com uma possibilidade de formar um grande e vasto conjunto de diferentes ligas combinando o alumínio com outros elementos químicos como $\mathrm{Mn}, \mathrm{Cu}, \mathrm{Mg}, \mathrm{Si}, \mathrm{Fe}, \mathrm{Ni}$, Li, com diferentes porcentagens [5]. Algumas das ligas criadas hoje possuem resistência mecânica superior aos aços estruturais.

\subsubsection{Ligas de alumínio}

Possuindo um elevado grau de pureza, o alumínio é um metal demasiado dúctil e pouco resistente para que possa ser usado em aplicações estruturais com exigências de esforços solicitantes. Deve-se mudar a sua forma quando forem 
submetidas a algumas alterações que the melhorem as propriedades mecânicas quando as aplicações assim o exigirem. Estas alterações passam, de uma forma geral, pela adição de elementos de liga, por submeter o metal a deformação mecânica resultando num encruamento ou, por sujeitar o material a tratamentos térmicos. No caso específico a adição de elementos de liga há uma melhora num aumento da resistência mecânica [6].

\subsubsection{Classificação das ligas de alumínio}

A International Alloy Designation System (IADS) criou um sistema de classificação das ligas trabalháveis que foram agrupadas em 8 grandes grupos. As ligas de Al são designadas conforme o elemento de liga principal em sua composição química, nesta designação existem 4 dígitos numéricos ( $X X X X)$, (TAB. II), sendo que o primeiro dígito indicará o principal elemento de liga. Para as ligas fundidas a classificação segue de forma parecida as ligas trabalháveis, na qual existem 3 dígitos numéricos seguido de um ponto e mais um dígito numérico (XXX.X).

TABELA II. Séries de ligas de alumínio e principais aplicações.

\begin{tabular}{lll}
\hline SÉRIE & COMPOSIÇÃO QUíMICA & PRINCIPAIS APLICAÇÕES \\
\hline 1XXX & Al comercialmente puro & Contatos elétricos \\
$2 X X X$ & Al-Cu e Al-Cu-Mg & Indústria aeronáutica \\
$3 X X X$ & Al-Mn e Al-Mn-Mg & Latas de bebidas, panelas \\
$4 X X X$ & Al-Si & $\begin{array}{l}\text { Metal de adição para soldas, pistões, } \\
\text { forjados de motores }\end{array}$ \\
$5 X X X$ & Al-Mg & Aplicações náuticas (navios e barcos) \\
$6 X X X$ & Al-Mg-Si & Arames, tubos extrudados e chapas \\
$7 X X X$ & Al-Zn e Al-Zn-Mg & Indústria aeronáutica \\
$8 X X X$ & Al-Sn & Não será comentado \\
$9 X X X$ & Ligas de pouco uso & Não será comentado \\
\hline
\end{tabular}

Além da classificação das séries quanto a composição química, a Associação brasileira de normas técnica (ABNT) também estabeleceu um sistema de classificação quanto ao tipo de tratamento térmico. Esta classificação está descrita na NBR - ISO 2107. O capítulo da normalização de têmperas descreve: 
F - como fabricado, $\mathrm{O}$ - recozido, $\mathrm{H}$ - encruado ,W - solubilizado (envelhecido naturalmente), $\mathrm{T}$ - tratado termicamente. A série $\mathrm{H}$ aplica-se as ligas da série 1000,3000 e 5000 e a série T para as ligas tratáveis termicamente $(2000,6000$ e 7000).

H1: encruado

$\mathrm{H} 2$ : encruado e recozido parcialmente

H3: encruado e estabilizado

Estas condições são classificadas em diferentes graus de encruamento:

$1-1 / 8$ duro

$2-1 / 4$ duro

$4-1 / 2$ duro

$6-3 / 4$ duro

8 - duro

9 - extra duro

Em conformidade com a NBR - ISO 2107 descrevem-se as etapas de processos, citando as literaturas dos autores [1,2]. Os processos têm sua aplicação nas seguintes aplicações: conformado em temperatura elevada, resfriado bruscamente e envelhecido naturalmente.

T1: Resfriado após conformação a elevada temperatura e envelhecido naturalmente.

T2: Apresenta-se diferente do anterior apresentando-se encruado antes do envelhecimento.

T3: Solubilizado, encruado e envelhecido naturalmente.

T4: Solubilizado e envelhecido naturalmente.

T5: Similar a T1, porem, envelhecido artificialmente.

T6: Solubilizado e envelhecido artificialmente.

T7: Solubilizado e super-envelhecido.

T8: Similar a T3, porém, envelhecido artificialmente.

T9: Solubilizado e envelhecido artificialmente e em seguida encruado.

T10: Resfriado após conformação em elevada temperatura, encruado e envelhecido artificialmente.

As outras definições são dadas a seguir:

F - Como fabricado - Desenvolvidos aos produtos forjáveis onde não existe controle quanto à quantidade de endurecimento ou ao tipo de tratamentos 
térmicos recebidos. Para esta designação não existem propriedades mecânicas especificadas.

O - Recozido - Denominação para produtos que são recozidos com o objetivo de produzirem a menor resistência possível. Pode-se apresentar acompanhado por um sufixo que indique o tratamento térmico.

$\mathrm{H}$ - Endurecido por encruamento - Tem como definição ao menos dois dígitos, que identificam a quantidade de encrua mento e o tratamento térmico que poderá ter submetido atingirem as propriedades mecânicas desejadas.

W - Tratamento de solubilização - Aplicada as ligas que passam por um envelhecimento natural após solubilização. Tem como pela informação do tempo de envelhecimento natural.

T - Tratado termicamente - Identifica as ligas que são envelhecidas para produzirem uma condição de estabilidade, tendo como identificação um ou mais dígitos que indicam a classificação do tratamento térmico ocorrido.

A TAB. III apresenta as principais ligas, características e aplicações típicas das ligas de alumínio trabalháveis.

TABELA III. Ligas de alumínio trabalháveis. *Adaptação para a liga 6082.

\begin{tabular}{lll}
\hline LIGA & CARACTERÍSTICAS & APLICAÇÕES \\
\hline 1050 & $\begin{array}{l}\text { Alumínio comercialmente puro, } \\
\text { muito dúctil no estado recozido, } \\
\text { indicado para deformação a frio. } \\
\text { Estas ligas têm excelente } \\
\text { resistência à corrosão, a qual é } \\
\text { crescente com o aumento da } \\
\text { pureza da liga. }\end{array}$ & $\begin{array}{l}\text { Equipamentos para indústrias } \\
\text { alimentícias, químicas, bebidas, } \\
\text { trocadores de calor ou utensílios } \\
\text { domésticos. }\end{array}$ \\
1350 & $\begin{array}{l}\text { Alumínio 99,5\% de pureza, com } \\
\text { condutibilidade mínima de 61\% } \\
\text { IACS. }\end{array}$ & $\begin{array}{l}\text { Barramentos elétricos, peças ou } \\
\text { equipamentos que necessitem de } \\
\text { alta condutibilidade elétrica. }\end{array}$ \\
2017 & $\begin{array}{l}\text { Ligas de AICu, com elevada } \\
\text { resistência mecânica, alta } \\
\text { ductibilidade, média resistência à } \\
2024\end{array}$ & $\begin{array}{l}\text { indústria aeronáúlica, transporte, } \\
\text { máquinas e equipamentos. }\end{array}$ \\
2217 & corrosão e boa usinabilidade. & \\
\hline
\end{tabular}


3003 Ligas de AIMn, com boa resistência à corrosão, boa conformabilidade $\mathrm{e}$ moderada resistência mecânica. São ligas de uso geral.

4043 Ligas de AISi utilizadas em varetas 4047 de solda.

5005 Ligas de AIMg são dúcteis no 5052 estado recozido, mas endurecem 5056 rapidamente sob trabalho a frio. Alta resistência à corrosão em ambientes marítimos. Em geral a resistência mecânica aumenta com os teores crescentes de Mg.

6053 Ligas de AIMgSi, tratáveis 6061 termicamente com excelente 6063 *6082 resistência mecânica na têmpera T6.

6351
Carrocerias de ônibus e de furgões, equipamentos rodoviários e veículos em geral, reboques, vagões, utensílios domésticos, equipamentos para indústria química e alimentícia, telhas, cumeeiras, rufos, calhas, forros, construção civil e fachadas.

Soldagem das ligas das séries 1XXX, 3XXX e 6XXX.

Carrocerias de ônibus e de furgões, equipamentos rodoviários $\mathrm{e}$ veículos em geral, estruturas solicitadas, reboques, vagões ferroviários, elementos estruturais, utensílios domésticos, equipamentos para indústria química e alimentícia, telhas, cumeeiras, rufos, calhas, forros, construção civil, fachadas e embarcações.

Carrocerias de ônibus e de furgões, equipamentos rodoviários $\mathrm{e}$ veículos em geral, estruturas solicitadas, reboques, vagões ferroviários, elementos estruturais, utensílios domésticos, equipamentos para indústria química e alimentícia, telhas, cumeeiras, rufos, calhas, forros, construção civil, fachadas e embarcações.

Peças sujeitas aos mais elevados esforços mecânicos em indústria aeronáutica, militar, máquinas e equipamentos, moldes para injeção de plástico.

Continuação TABELA III. Ligas de alumínio trabalháveis. *Adaptação para a liga 6082.

\subsubsection{Liga AA-6082}

Entre as ligas de alumínio da série $6 \mathrm{XXX}$, a liga AA-6082 tem a mais alta resistência e é conhecida como uma liga estrutural. A adição de uma grande quantidade de manganês controla a estrutura do grão, que por sua vez resulta em uma liga mais forte. A ductilidade é relevante em se tratando da conformação com 
relação à deformação final e as propriedades mecânicas apresentados neste material. Nas áreas de aplicação do setor automotivo é necessária a alta resistência como forma de aumentar as características de conformação mecânica das ligas de alumínio [7,8]. As ligas da série $6 \mathrm{XXX}$ têm sido amplamente estudadas e usadas devido a sua importância tecnológica e ao aumento significativo da sua resistência mecânica obtido pelos mecanismos de endurecimento por precipitação. Dependendo do tratamento aplicado, no caso T6. A liga apresenta propriedades mecânicas ligeiramente superiores á liga 6061. A Liga AA-6082 também oferece boas características de acabamento e responde bem a anodização. Os métodos mais comuns de anodização incluem a anodização fosca, fosca colorida e dura. A liga 6082 oferece boa soldabilidade, brasabilidade, resistência à corrosão, conformabilidade e usinabilidade. Quando for conformar ou dobrar a liga AA-6082, é recomendado usar-se têmpera O ou T4. Para aplicações de usinagem, a liga AA-6082 oferece melhores características em condições de têmperas T5 ou T6. Os cavacos da usinagem podem ser de difícil quebra, então é recomendado o uso de quebradores de cavaco ou técnicas especiais de usinagem. Para determinadas secções de paredes finas, a têmpera T6 pode não ser útil devido às limitações de têmpera da liga. Vários métodos comerciais de soldagem e brasagem podem ser facilmente aplicados na liga 6082 [9-13].

A liga AA-6082 tem suas aplicações em diversos seguimentos: ferroviário nas suas estruturas pesadas, pontes militares, caldeiraria, construção naval, chassis de caminhões, pontes, bicicletas, máquinas para as plataformas, flanges, sistemas hidráulicos, equipamentos de mineração, postes e torres, barcos a motor, tecnologia nuclear, mastros e vigas para construção de navios (especialmente para água doce), tubos para andaimes quadro, para tendas e salões, encanamentos, tubulações. Além da utilização em elementos de fixação tais como parafusos e rebites.

\subsection{Processos na utilização das ligas de alumínio-extrusão}

O processo de transformação mecânica do alumínio consiste na redução da seção transversal por compressão do metal na passagem através de dois cilindros constituídos de aço ou ferro fundido com eixos paralelos operando com giros em torno de si mesmos com arranjos dos cilindros de cinco maneiras 
diferentes conforma a necessidade (FIG. 1). No caso da geometria das peças apresentarem-se com seção transversal retangular e denominam-se produtos laminados planos de alumínio e suas ligas, apresentando-se em chapas grossas com espessuras de $150 \mathrm{~mm}$, com aplicação nas áreas de usinas atômicas, até folhas com espessura de 0,005 mm em condensadores. Há dois processos apresentados usualmente na laminação de alumínio: á quente e a frio. Atualmente, a indústria também se utiliza da laminação contínua [1,14-15].

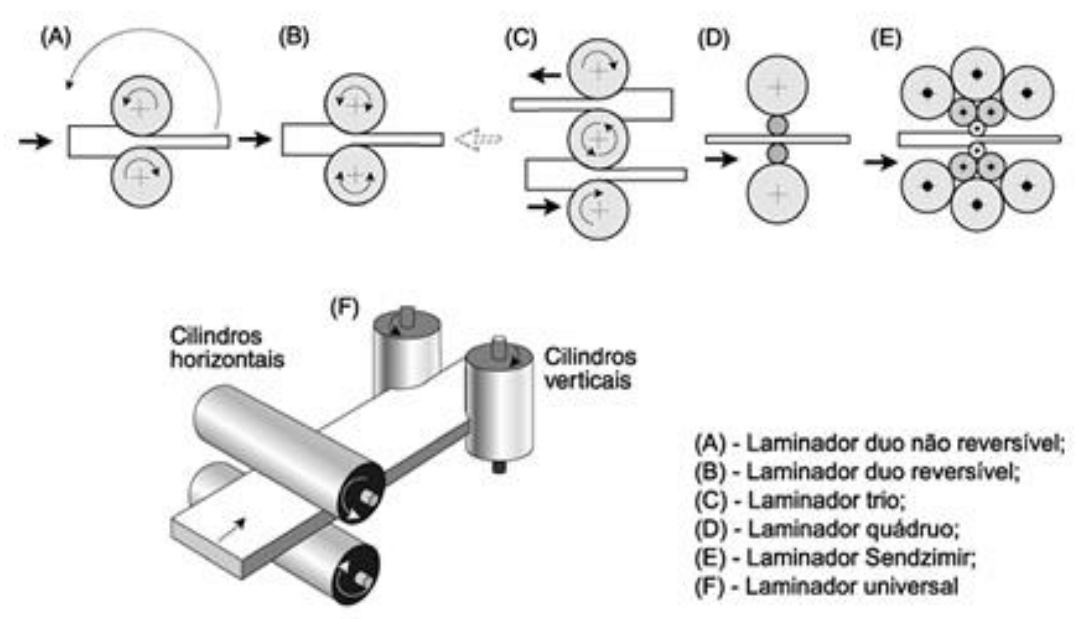

Figura 1. Redução da espessura da chapa pelo método de laminação.

Nos processos de laminação classificam-se os principais produtos laminados tais como, chapas planas ou bobinadas, folhas e discos. Nas áreas de aplicação inclui-se a semimanufatura com atuação nos setores como transportes (carrocerias para ônibus, equipamentos rodoviários, elementos estruturais.), construção civil (telhas, fachadas, calhas e rufos), embalagens (latas, descartáveis e flexíveis) e bens de consumo (panelas, utensílios domésticos).

\subsubsection{Laminação a quente}

Promove reduções da seção transversal com o metal a uma temperatura mínima de aproximadamente $350 \stackrel{\circ}{\circ} \mathrm{C}$ (igual à temperatura de recristalização do alumínio). A ductilidade do metal a temperaturas desta ordem é máxima e, nesse processo ocorre á recristalização dinâmica na deformação plástica. $O$ processo transcorre da seguinte forma:

1) Uma placa (matéria-prima inicial), cujo peso varia de alguns quilos até 
15 toneladas, é produzida na refusão, por meio de fundição semicontínua, em molde com seção transversal retangular. Este tipo de fundição assegura a solidificação rápida e estrutura metalúrgica homogênea. A placa pode sofrer uma usinagem superficial (faceamento) para remoção da camada de óxido de alumínio, dos grãos colunares (primeiro material solidificado) e das impurezas provenientes da fundição.

2) Posteriormente, a placa é aquecida até tornar-se semiplástica.

3) A laminação a quente se processa em laminadores reversíveis duplos (dois cilindros) ou quádruplos (dois cilindros de trabalho e dois de apoio ou encosto).

4) O material laminado é deslocado, a cada passada, por entre os cilindros, sendo que a abertura dos mesmos define a espessura do passe. A redução da espessura por passe é de aproximadamente $50 \%$ e depende da dureza da liga que está sendo laminada. No último passe de laminação, o material apresenta-se com espessura ao redor de $6 \mathrm{~mm}$, sendo enrolado ou cortado em chapas planas, constituindo-se na matéria-prima para o processo de laminação a frio.

Concepções mais modernas do processo de laminação a quente podem apresentar em linha, após o desbastamento, em um laminador reversível, uma cadeia de vários laminadores, denominada de "tandem", que reduz a espessura do material para cerca de $2 \mathrm{~mm}$. Uma unidade de laminação a quente contém: laminador, refusão (unidade de fundição de placas), fornos de pré-aquecimento para placas, tratamentos térmicos de homogeneização (distribuição mais homogênea dos elementos micro constituintes químico-metalúrgicos), tesouras rotativas e guilhotinas para cortes laterais e longitudinais do material laminado, serras para cortes das extremidades e faceadeira para usinagem das superfícies.

\subsubsection{Laminação a frio}

Realiza-se a temperaturas bem inferiores às de recristalização do alumínio. A matéria-prima é oriunda da laminação a quente. A laminação a frio é executada, geralmente, em laminadores quádruplos, reversíveis ou não, sendo este último mais empregado como pode ser observado na FIG. 2. O número de passes depende da espessura inicial da matéria-prima, da espessura final, da liga e da têmpera do produto desejado. Os laminadores estão dimensionados para 
reduções de seções entre $30 \%$ e $70 \%$ por passe, dependendo, também, das características do material em questão. Laminadores mais sofisticados possuem sistemas computadorizados de controle de espessura e de planicidade.

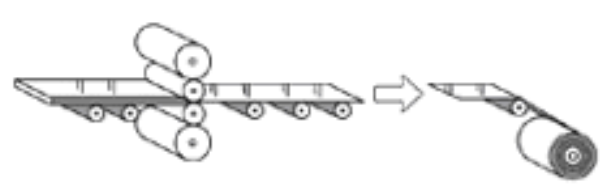

Laminação a frio

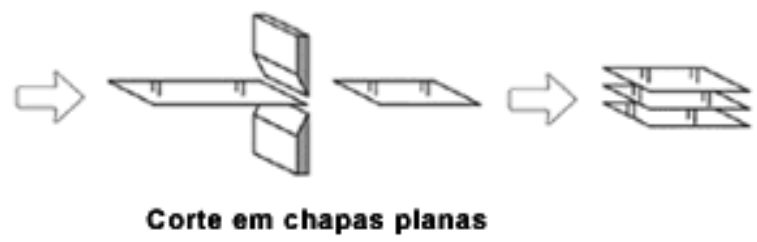

Figura 2. Esquema de laminador quádruplo empregado na laminação a frio.

$\mathrm{Na}$ laminação a frio utilizam-se dois recursos: tensões avante e tensões a ré. Ambas aliviam o esforço de compressão exercido pelos cilindros ou aumentam a capacidade de redução por passe. Estes recursos são também responsáveis pela redução da espessura no caso de laminação de folhas finas, em que os cilindros de laminação estão em contato e praticamente sem abertura perceptível.

Outro processo atualmente muito utilizado é o de laminação contínua que elimina a etapa de laminação a quente. O alumínio é solidificado entre dois cilindros refrigerados internamente por água, que giram em torno de seus eixos, produzindo uma chapa com seção retangular e espessura aproximada de $6 \mathrm{~mm}$. Posteriormente, esta chapa é enrolada, obtendo-se assim um produto similar àquele obtido por laminação a quente. Porém, este produto apresentará uma estrutura bruta de fusão bastante refinada, dada a alta eficiência do refinador de grão utilizado no vazamento.

A deformação a frio confere o encruamento ao alumínio. Aumenta os limites de resistência à tração e ao escoamento, com diminuição do alongamento. Esse procedimento produz um metal com bom acabamento superficial e preciso controle dimensional.

Os produtos laminados de alumínio são utilizados em todas as operações metalúrgicas usuais de chapas, incluindo aquelas que exigem do metal de excepcional ductilidade, como é o caso de processos como estampagem, extrusão por impacto, perfilação (roletagem). Recozimentos intermediários podem ser realizados para amolecimento (recristalização) e para facilitar posterior laminação ou determinar têmperas específicas.

Os produtos laminados a frio mais finos (folhas), com espessura de até 
0,005 mm, são produzidos em laminadores específicos, que concebem o processo de laminação de folhas dupladas com lubrificação entre elas.

\subsection{Conformação por spray}

O processo de conformação por spray vem despertando interesse nos últimos anos devido à capacidade de conjugar em uma única etapa do processo as vantagens das técnicas de solidificação rápida, como obtenção de microestrutura quase isenta de porosidade, segregações e refinada, com as vantagens do processo de fundição convencional, como alta produtividade. As pesquisas estão levando ao desenvolvimento de técnicas de melhoramento das ligas e materiais. No caso específico das ligas de alumínio houve progresso devido ao desenvolvimento de métodos de produção como a metalurgia do pó e conformação por spray [16]. Estes métodos ocorrem por processos de solidificação rápida e permitem obter ligas com composições diferentes das obtidas pelos processos de lingotamento convencional.

O processo de conformação por spray consiste na atomização por gás inerte de um jato de metal líquido, transformando-o em várias gotas de tamanhos variados, sendo que a trajetória destas gotas é interrompida por um substrato sobre o qual elas solidificam na forma de um depósito com microestruturas refinadas com baixo nível de segregação e soluções sólidas supersaturadas com fases metaestáveis [17].

A habilidade deste processo é de desenvolver produtos em diversas formas (placas, discos, tubos e outros produtos) com microestruturas refinadas diretamente a partir do metal fundido oferecendo grande benefício em comparação ao lingotamento convencional. O sucesso da técnica depende do entendimento e controle de vários parâmetros de processo: superaquecimento do banho, movimento do substrato (velocidade e inclinação angular do substrato), diâmetro do bocal de vazamento de metal, tipo de gás de atomização, tipo de bocal atomizador, material do substrato e a razão da vazão mássica de gás para a vazão mássica de metal.

As ligas de alumínio AA-6082 [18,19] são ligas de alta resistência do sistema Al-Mg-Si endurecíveis por precipitação, contudo muitas destas ligas sofrem adições de cobre para melhorar sua resistência ao trincamento atribuível à corrosão sob tensão. Há, porém, uma importante gama de ligas de média 
resistência contendo pouco ou nenhum cobre que têm a vantagem de ser prontamente soldável. Estas ligas diferem de outras ligas soldáveis de alumínio devido ao envelhecimento por precipitação ocorrer à temperatura ambiente.

\subsubsection{A conformação por spray}

A conformação por spray é constituído por diversas etapas. Na primeira um gás inerte em alta velocidade flui através dos bocais transformando o metal líquido em gotículas. Durante a atomização as pequenas gotas (que são semisólidas) são coletadas numa pré-forma em formato de disco metálico e submetidas a giro e movimento ascendente.

O controle do movimento da pré-forma e das condições de atomização produz tarugo (peça) com diâmetros de até $400 \mathrm{~mm}$ e $2,5 \mathrm{~m}$ de comprimento. Placas e tiras de até $1 \mathrm{~m}$ de largura e espessura maior que $5 \mathrm{~mm}$ podem ser produzidas em um modo semicontínuo através da largura de uma correia horizontal [20-23]. A FIG. 3 esquematiza o processo de obtenção de preformado.
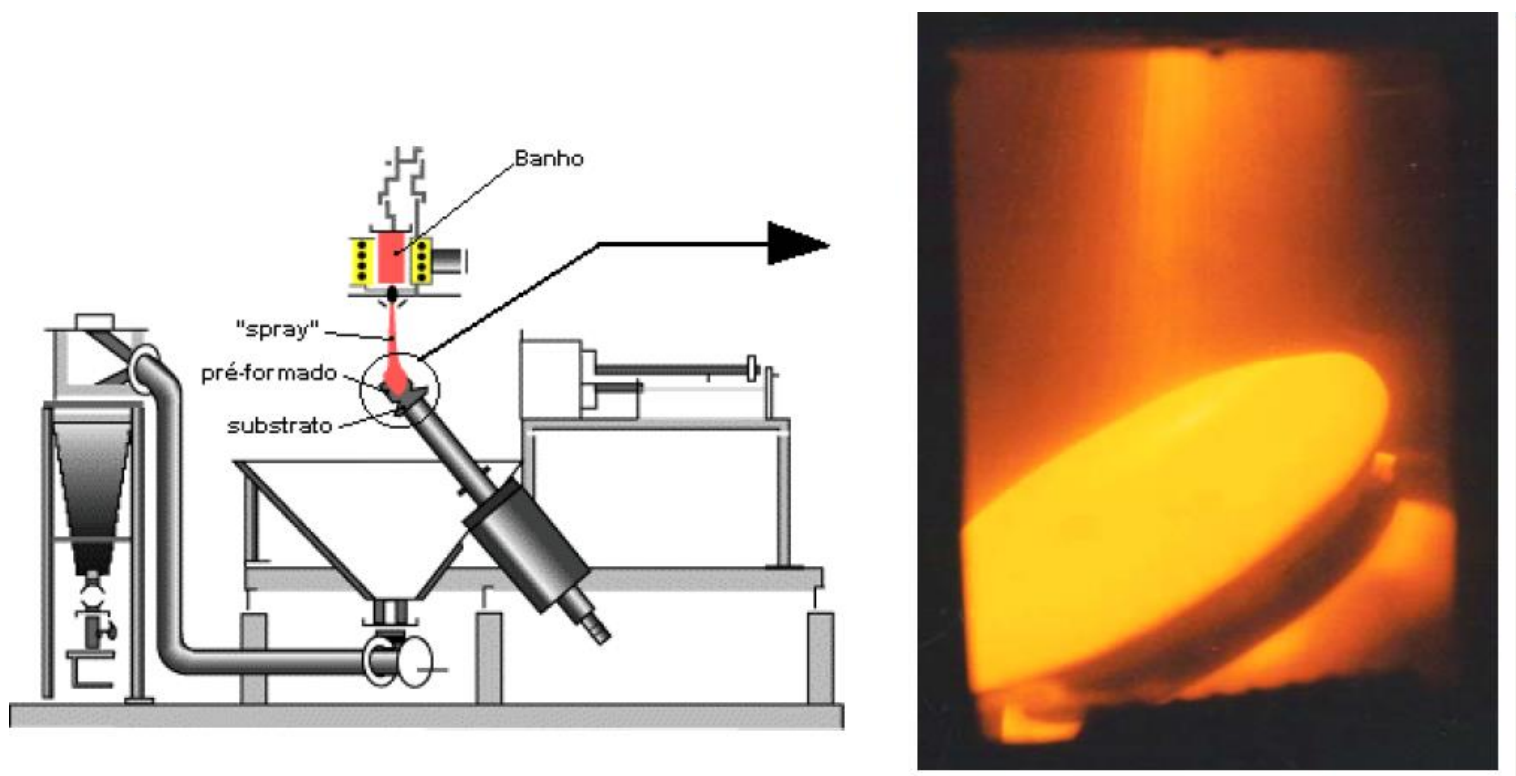

Figura 3. Processo de conformação por spray com jato único na direção do substrato [24].

No processo de conformação por spray, não apenas para as ligas de alumínio, como também de materiais ferrosos a literatura relata sobre o refino de grãos de sua uniformidade de uma matriz isenta de porosidade e inclusões que possam fragilizar a estrutura do material. 


\subsubsection{Parâmetros do processo Osprey}

A FIG. 4 apresenta um esquema de mecanismo de conformação por spray indicando os parâmetros que influenciam a obtenção da microestrutura desde do banho no forno de indução até o preformado sobre o substrato $[25,26]$.

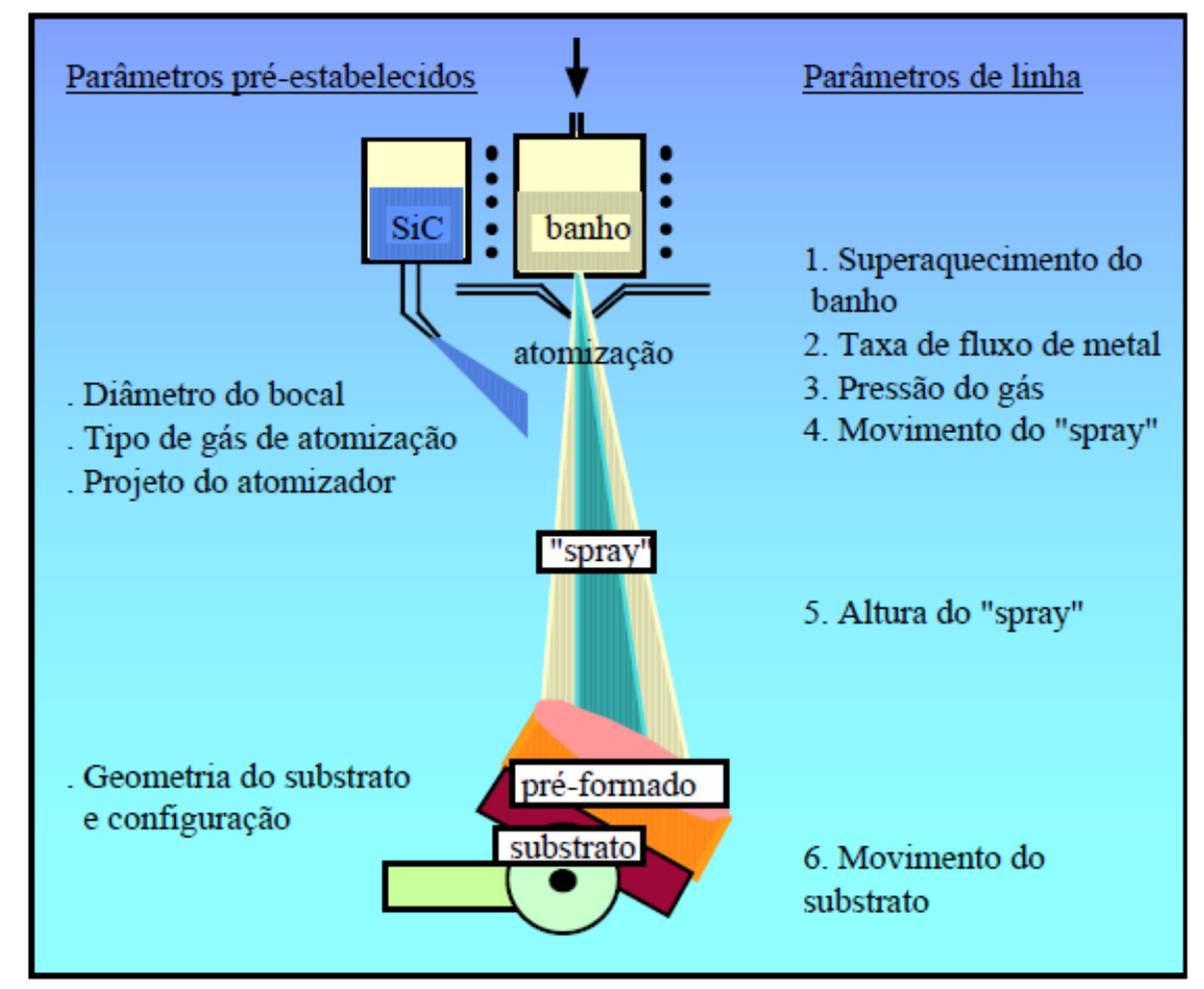

Figura 4. Desenho esquemático do processo Osprey de conformação por spray [19].

O resultado da microestrutura pode ser alterado pelos parâmetros do processo Osprey das seguintes formas:

1. A viscosidade do banho do material fundido pode alterar a taxa de alimentação.

2. A abertura do orifício de vazamento permite ajustar o fluxo.

3. A pressão do gás atomizante e as características geométricas do atomizador definem o fluxo de gás e de alimentação do metal, permitindo se controlar a distribuição do tamanho de gotículas e a velocidade de resfriamento destas.

4. O orifício do tubo de vazamento em função da distância do substrato e a velocidade de resfriamento definem a quantidade de fase líquida presente nas gotículas metálicas em cada posição do vôo, exercendo influência sobre a capacidade de incorporação de partículas de reforço na matriz metálica. 
5. A pressão usada para a injeção de partículas de reforço;

6. O número, a localização espacial dos injetores cônicos, suas regulagem para a taxa de alimentação de partículas injetadas e suas orientações. Tudo isto contribui para a fração volumétrica de reforço incorporada no sólido depositado;

7. A fração volumétrica de líquido presente nas gotículas antes do impacto com o substrato;

8. O valor do coeficiente de transferência de calor durante o estágio de deposição. No processo de conformação por spray, não apenas para as ligas de alumínio, como também de materiais ferrosos a literatura relata sobre o refino de grãos de sua uniformidade de uma matriz isenta de porosidade e inclusões que possam fragilizar a estrutura do material. 


\section{PROCEDIMENTO EXPERIMENTAL}

\subsection{Material}

Neste trabalho foi utilizada como carga do forno ou material de partida um tarugo comercial cuja composição foi determinada por espectrofotometria de absorção atômica (TAB. IV).

TABELA IV. Composição química do material de partida (\% massa), antes da conformação por spray, obtida por espectrofotometria de absorção atômica.

\begin{tabular}{|c|c|c|c|c|c|c|c|c|c|c|c|c|}
\hline \multicolumn{13}{|c|}{ Elemento } \\
\hline $\mathrm{Al}$ & $\mathrm{Si}$ & $\mathrm{Fe}$ & $\mathrm{Cu}$ & $\mathrm{Mn}$ & $\mathrm{Pb}$ & $\mathrm{Mg}$ & $\mathrm{Cr}$ & $\mathrm{Ni}$ & $\mathrm{Zn}$ & Sn & $\mathrm{Ti}$ & V \\
\hline 96,72 & 0,94 & 0,31 & 0,06 & 0,99 & 0,02 & 0,86 & 0,007 & 0,01 & 0,02 & 0,02 & 0,02 & 0,02 \\
\hline
\end{tabular}

\subsection{Métodos}

Foram feitas análises no material segundo algumas etapas, com a finalidade de caracterizá-lo, verificando o comportamento deste conforme as novas condições impostas. Para melhor entender este trabalho foi estabelecido as etapas mais importantes conforme os testes e análises realizado. São elas:

I. Obtenção e determinação da composição da peça matriz;

II. Conformação por spray (preformado);

III. Cortes em posições específicas do preformado (base "B" e topo "T");

IV. Análises de dureza Vickers e microscopia óptica antes do tratamento térmico em posições da base (borda, meio e centro) e topo (borda, meio e centro);

V. Tratamento térmico (solubilização e envelhecimento);

VI. Novos testes de dureza Vickers e microscopia óptica após cada tratamento térmico.

\subsection{Caracterização}

\subsubsection{Material preformado}

Para a realização deste trabalho foi utilizado um material conformado por spray na planta instalada no CCTM-IPEN [19]. Este preformado apresentou as seguintes dimensões: A parte esquerda (lado maior) denominou-se topo com diâmetro de $230 \mathrm{~mm}$ e a parte direita (lado menor) do preformado denominou-se 
base com diâmetro de $160 \mathrm{~mm}$. A peça tem comprimento total de $500 \mathrm{~mm}$ como pode ser observado na FIG. 5. Este preformado apresentou uma variação de diâmetro devido a ajustes iniciais das condições de operação da planta de conformação e não é representativo da capacidade de se obter preformados com variação de diâmetro menor que 5\%. Operações sucessivas da planta demonstraram esta capacidade.

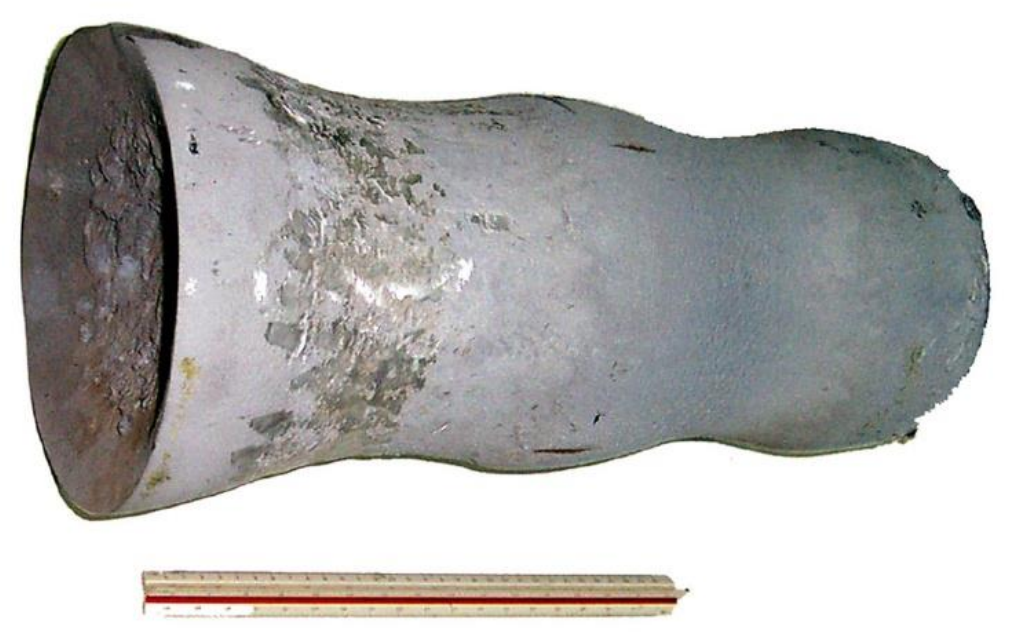

Figura 5. Preformado com diâmetro maior denominado base e diâmetro menor lado base nas dimensões.

O preformado foi cortado em duas superfícies no lado base e lado do topo da peça como pode ser visto na FIG. 6 .
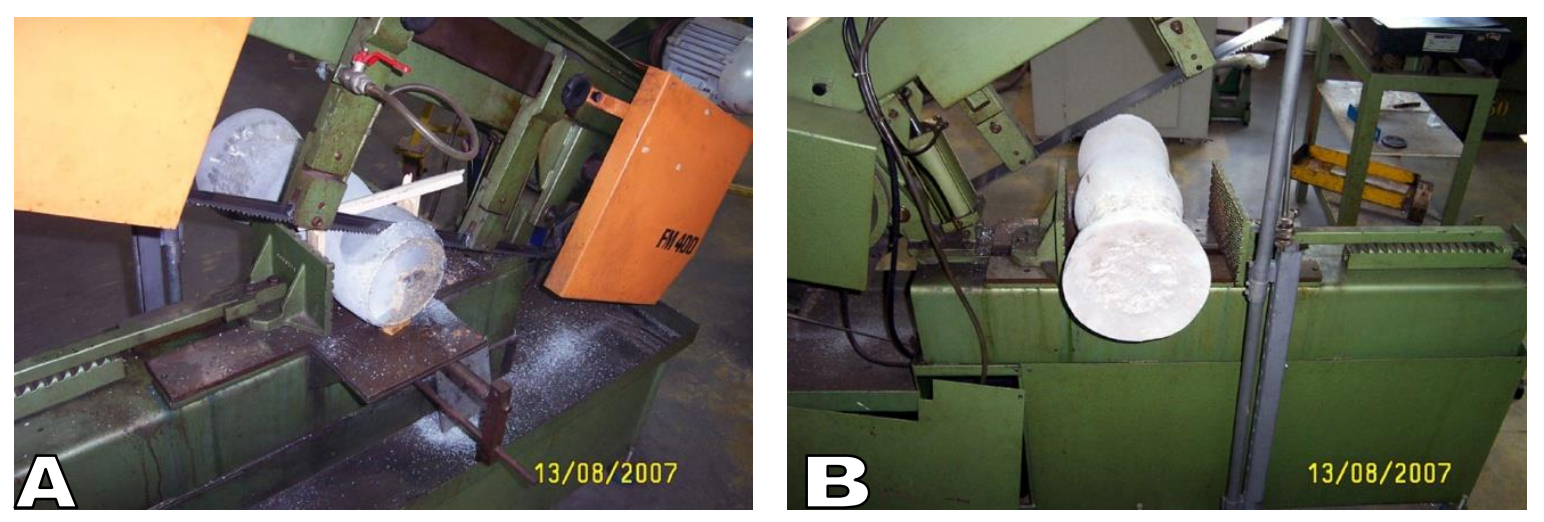

Figura 6. Visualização do preformado: base (A) e topo (B), em processo de corte.

Estas amostrar da base e topo foram divididas em 20 secções das quais foram retiradas amostras radiais, denominadas de borda, meio e centro (FIG. 7). 
Nestas amostras, foram determinadas as durezas Vickers com carga de 31,25, kgf, foi feita a microscopia óptica, antes e após o tratamento térmicos de envelhecimento e solubilização.

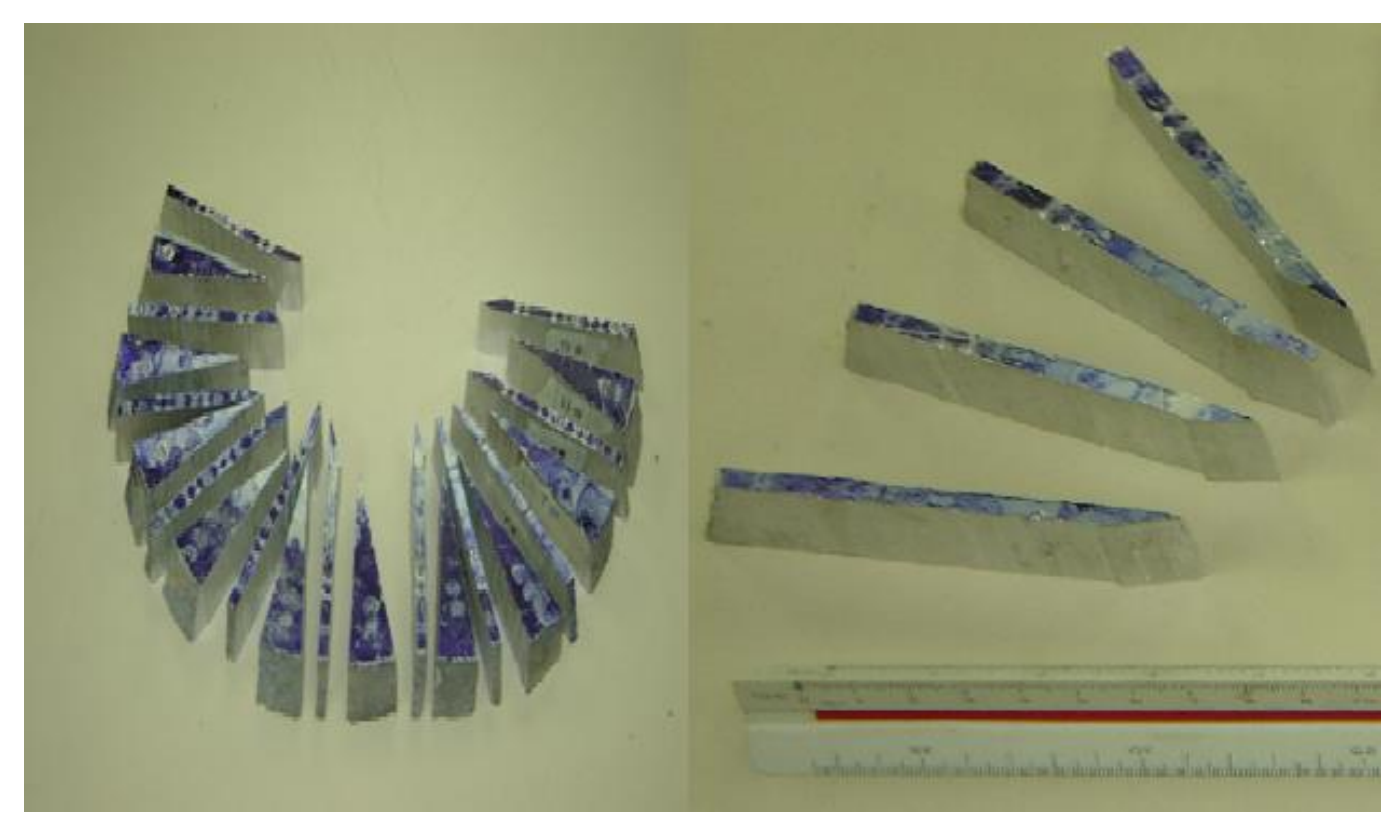

Figura 7. Esquema do corte das amostras situado na base e topo do preformado.

Foi utilizado álcool para corte da peça como fluído refrigerante, com isso evitou-se o aquecimento podendo comprometer as características. Nestas 20 peças foram realizadas 3 indentações em cada trecho ou seja 3 na borda, 3 no meio e 3 no centro. Para melhor entendimento nas tabelas de dureza Vickers será feito a seguir a descrição de cada área para análise.

\subsubsection{Análise química do preformado}

O ensaio químico foi realizado pelo método de espectrofotometria de absorção atômica com equipamento de marca Gemine (Varian). Procedimento: conforme norma do fabricante do equipamento.

\subsubsection{Microscopia óptica}

Foi realizado a microscopia óptica (MO) do material de partida, no material conformado por spray e no material solubilizado. Todas as amostras sofreram o ataque com ácido fluorídrico e álcool etílico. 


\subsubsection{Preparação dos corpos-de-prova}

Foram realizados cortes na serra de fita horizontal, seccionando as partes. As amostras foram primeiramente preparadas por lixamento passando pelas seguintes classificações de lixas 300, 400 e 600, sendo posteriormente polidas com pasta de diamante $1 \mu \mathrm{m}$. Tal procedimento revelou uma superfície lisa, isenta de porosidades.

\subsubsection{Lixamento e polimento}

As amostras do material como fabricado e após tratamentos térmicos foram embutidas em resina a frio. As amostras foram então preparadas por lixamento manual em lixas de grana 320, 400, 600 e 1200, sendo posteriormente polidas, também manualmente, com pasta de diamante de 6, 3 e $1 \mu \mathrm{m}$. $\mathrm{O}$ acabamento final foi realizado com uma suspensão de sílica coloidal 0,06 $\mu \mathrm{m}$, em uma politriz automática. Tal procedimento permitiu a obtenção de uma superfície lisa, isenta de riscos, possibilitando assim estudar-se a porosidade e, posteriormente, a microestrutura não modificadas por ataques químicos.
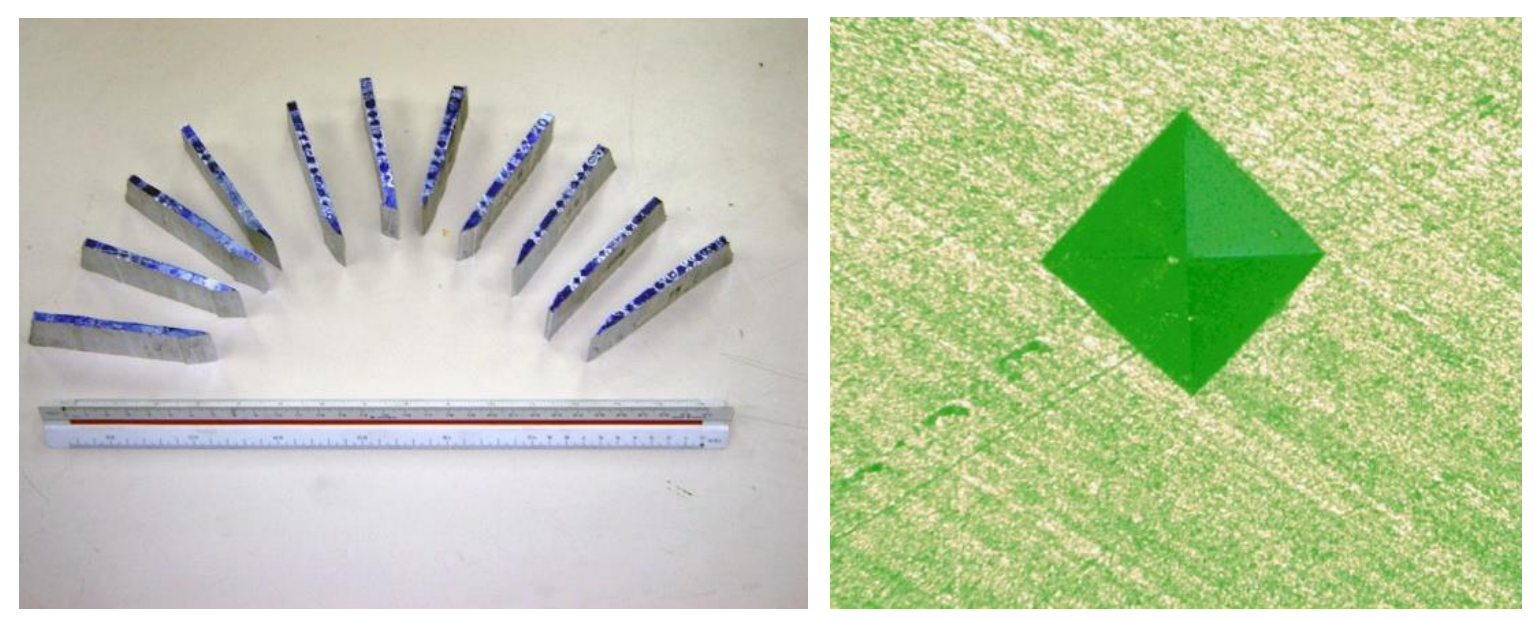

Figura 8. Exemplo típico de indentação de dureza Vickers com carga de 31,25 kgf usada em todo o experimento.

\subsubsection{Tratamento térmico}

Foram realizados tratamentos térmicos de solubilização na temperatura de $525 \stackrel{\circ}{ } \mathrm{C}$, no tempo de $1 \mathrm{~h}$, seguido de envelhecimento na temperatura de $125{ }^{\circ} \mathrm{C}$ nos períodos de $1 \mathrm{~h}, 10 \mathrm{~h}, 100 \mathrm{~h}$ e $500 \mathrm{~h}$. Houve interferências na continuidade do tratamento térmico de solubilização e envelhecimento no período de $500 \mathrm{~h}$. Nos 
processos de tratamento térmico houve a indisponibilidade operacional devido à falta de energia. Nos períodos críticos de chuvas ocorreram eventos em maior número. As contínuas interrupções nos circuitos da rede de distribuição aérea de 13.800 Volts, abastecidos pela concessionária de energia elétrica, a empresa AES - Eletropaulo que é operado pela equipe de manutenção contratada pela Universidade de São Paulo.

As peças do preformado foram partidas em formato de pastilhas para tratamento térmico. Para minimizar a variação e gradientes de temperatura dentro do forno, foram usinados blocos de alumínio que serviram de suporte e massa térmica para as amostras. A FIG. 9 mostra algumas amostras e o forno com a carga de amostras e os blocos de suporte. A FIG. 10 mostra o forno em operação.
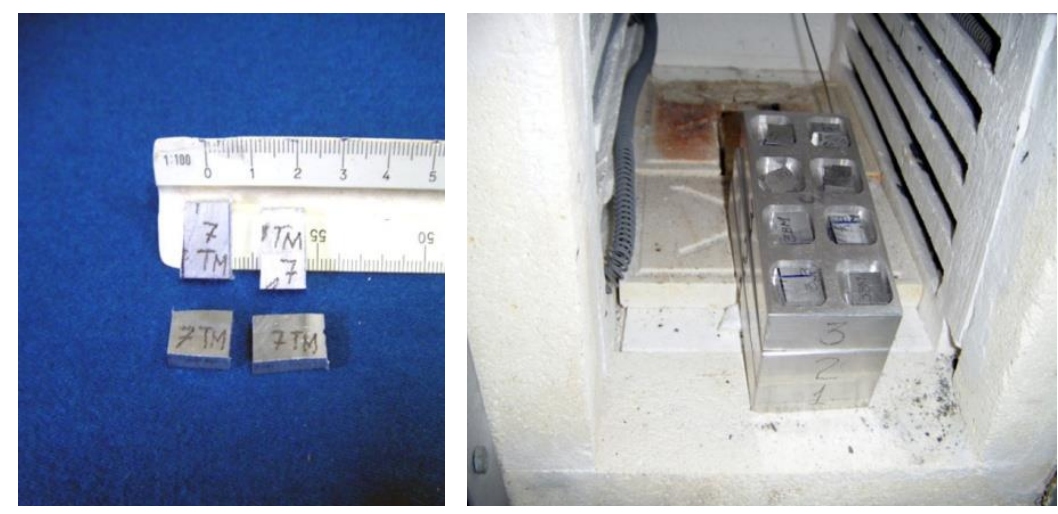

Figura 9. Massa térmica com três blocos, termopar anexo no forno carregado com as amostras. As peças do preformado foram partidas em formato de pastilhas para tratamento térmico.

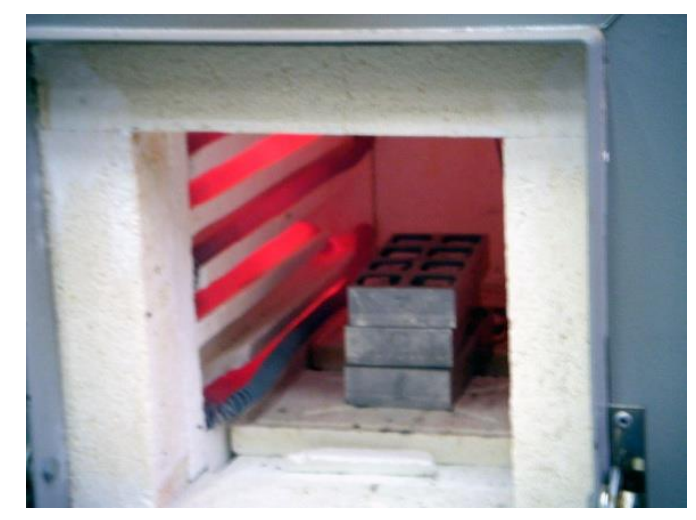

Figura 10. Massa térmica com três blocos e o termopar anexo com forno em operação, na temperatura de $525^{\circ} \mathrm{C}$. 


\section{RESULTADOS E DISCUSSÃO}

\subsection{Composição química}

Nas partes estudadas do preformado denominada de topo e base a composição química após o processo de conformação por spray apresenta-se inalterada sem diferença de elementos na composição química. São mantidos os mesmo valores dos parâmetros analisados os seguintes elementos químicos expressos em porcentagem em massa:

Cu 0,04

Ni 0,001

$\mathrm{Pb} 0,001-0,003$

Cr $0,17-0,18$

Zn $0,004-0,003$

Sn 0,001

V $0,02-0,03$

Os outros elementos tais como $\mathrm{Mn}, \mathrm{Mg}$, apresentam percentual centesimal, estando em conformidade com a norma ABNT NBR-6834. Para o elemento químico $\mathrm{Fe}$ a composição química no trecho da base com a percentagem de 0,39\% e na área de topo $0,28 \%$ considerando que a origem o material como recebido antes do processo de conformação por spray é de $0,31 \%$.

Conforme a norma ABNT NBR-6834 a variação deste elemento é de 0,15 até $1,2 \%$. Atuando como refinador de grão, isso não se aplica para as ligas de silício. O ferro tem a propriedade de reduzir a contração e a fluidez [6]. A composição química foi realizada nas duas seções do preformado, a seção superior e inferior, TAB. V e VI. De acordo com os resultados da composição química da liga conformada por spray, o preformado permaneceu sem perdas substanciais durante o processamento, o que prejudicaria as propriedades mecânicas da liga. Existem pequenas variações, mas os resultados globais são mantidas dentro da variação química nominal esperado para a liga. 
TABELA V. Composição química do material conformado por spray (\% massa) obtida por espectrofotometria de absorção atômica denominado lado superior (topo).

\begin{tabular}{ccccccccccccc}
\hline \multicolumn{11}{c}{ Elemento } \\
\hline $\mathrm{Al}$ & $\mathrm{Si}$ & $\mathrm{Fe}$ & $\mathrm{Cu}$ & $\mathrm{Mn}$ & $\mathrm{PB}$ & $\mathrm{MG}$ & $\mathrm{Cr}$ & $\mathrm{Ni}$ & $\mathrm{Zn}$ & $\mathrm{Sn}$ & $\mathrm{Ti}$ & $\mathrm{V}$ \\
\hline 96,61 & 1,22 & 0,39 & 0,04 & 0,74 & 0,001 & 0,74 & 0,17 & 0,001 & 0,004 & 0,001 & 0,05 & 0,03 \\
\hline
\end{tabular}

TABELA VI. Composição química do material conformado por spray (\% massa) obtida por espectrofotometria de absorção atômica denominado lado inferior (base).

\begin{tabular}{ccccccccccccc}
\hline \multicolumn{11}{c}{ Elemento } \\
\hline $\mathrm{Al}$ & $\mathrm{Si}$ & $\mathrm{Fe}$ & $\mathrm{Cu}$ & $\mathrm{Mn}$ & $\mathrm{PB}$ & $\mathrm{MG}$ & $\mathrm{Cr}$ & $\mathrm{Ni}$ & $\mathrm{Zn}$ & $\mathrm{Sn}$ & $\mathrm{Ti}$ & $\mathrm{V}$ \\
\hline 96,79 & 1,18 & 0,28 & 0,04 & 0,69 & 0,003 & 0,76 & 0,18 & 0,001 & 0,003 & 0,001 & 0,05 & 0,02 \\
\hline
\end{tabular}

\subsection{Ensaios de dureza Vickers}

Foram executados ensaios de dureza Vickers, pode-se observar pelas informações da norma ASTM - American Society for Testing and Materials quanto ao centro da impressão não deverá estar mais próximo de alguma aresta do corpo de prova ou de outra impressão do que uma distância igual a 2,5 vezes o comprimento da diagonal da impressão [10]. Quando um material laminado é testado, a superfície de ligação deverá ser considerada como uma extremidade para os cálculos do espaçamento de indentação. Para a citação no texto usou-se a norma da ABNT-NBR 10520.

Foram elaborados os perfis de dureza de acordo com os valores obtidos nos ensaios, o que permitiu avaliar-se as propriedades de dureza ao longo do preformado obtido. Verificou-se uma boa heterogeneidade de dureza no material, considerando que todo o processo de obtenção do mesmo é gerenciado por um sistema computadorizado. Os resultados apresentados se mantém de forma normal devido a poucas variações nos níveis de dureza Vickers.

Notou-se que há variações de pequena ordem, conforme descrito nos gráficos mencionados contendo representações de níveis para se ter uma visão do plano de topo e base. As representações evidenciam os planos e dão uma idéia da topografia dos níveis e pequenos desníveis que são observados neste 
trabalho.

Os ensaios de dureza foram executados em condições padronizadas, originando os resultados significativos para análise sendo utilizado um campo de atuação de amostras para boa parte da varredura do preformado, para se ter dados assertivos quando as análises.

Os ensaios de dureza Vickers mostraram que existem variações, conforme descrito nos gráficos, vide FIGs. 11 e 12, com os níveis de representação para o plano de topo e base. Os perfis de dureza para ambas as secções de base e topo mostram uma variação radial com dureza da seção central menor que a média e borda região. Isto foi provavelmente devido a uma característica do processo de conformação por spray que mantém as regiões exteriores do preformado mais refrigeradas, diretamente relacionado ao fluxo de gás de atomização, do que a região central, que é mais propensa a recalescência devido a transformações de fase que ocorrem durante o resfriamento.

A solubilização a $525 \stackrel{\circ}{ } \mathrm{C}$ por $1 \mathrm{~h}$, aumentou a dureza do preformado da liga AA 6082, ver FIGs. 13 e 14. A dureza aumentou de $51 \pm 2 \mathrm{HV}$ a $77 \pm 2 \mathrm{HV}$ na condição como conformado por spray para solubilizada, respectivamente. Esta variação foi provavelmente devido a uma melhor distribuição dos elementos de liga, principalmente os mantidos em solução sólida. $O$ tratamento térmico também propiciou a obtenção de uma microestrutura mais homogênea. Os perfis de dureza de acordo com as direções radial foram mais semelhantes entre o núcleo, média e regiões de borda.

Após a solubilização por $1 \mathrm{~h}$ a $525{ }^{\circ} \mathrm{C}$, os tratamentos térmicos de envelhecimento a $125^{\circ} \mathrm{C}$ por $1 \mathrm{~h}, 10 \mathrm{~h}, 100 \mathrm{~h}$ e $500 \mathrm{~h}$ aumentaram a dureza da liga, vide FIGs. 14 a 22. Houve um ligeiro aumento para o $1 \mathrm{~h}$ e $10 \mathrm{~h}$ nos processo de tratamento térmico por envelhecimento, analisando-se os perfis de dureza contata-se que eles foram muito semelhantes. A dureza aumentou de $77 \pm 2 \mathrm{HV}$ da solução tratada desde a $84 \pm 1$ e $83 \pm 2$ para o 1 h e 10 h de envelhecimento, respectivamente. No período de 100 e $500 \mathrm{~h}$ de envelhecimento aumentou a dureza de $97 \pm 7$ e $98 \pm 5 \mathrm{HV}$, respectivamente. Isto significa que a dureza teve uma estabilidade no material e esta pode ser atingido um patamar as $100 \mathrm{~h}$ de envelhecimento a $125^{\circ} \mathrm{C}$. 


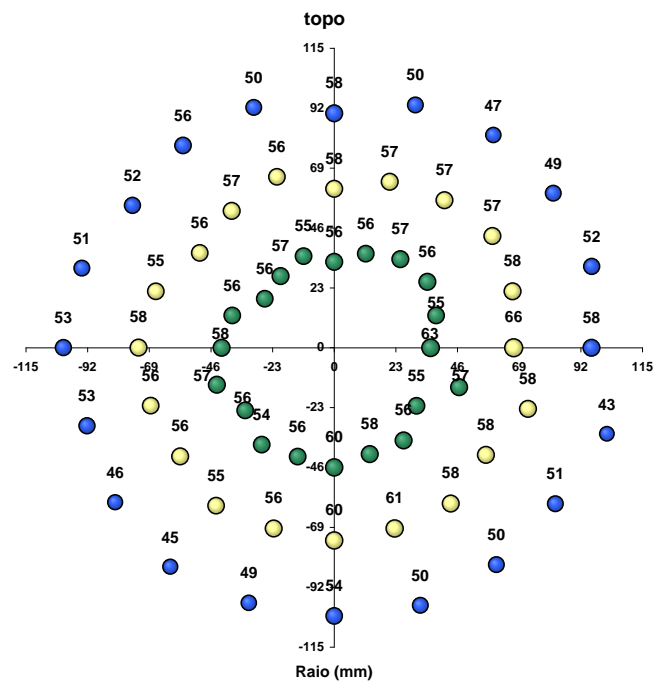

a)

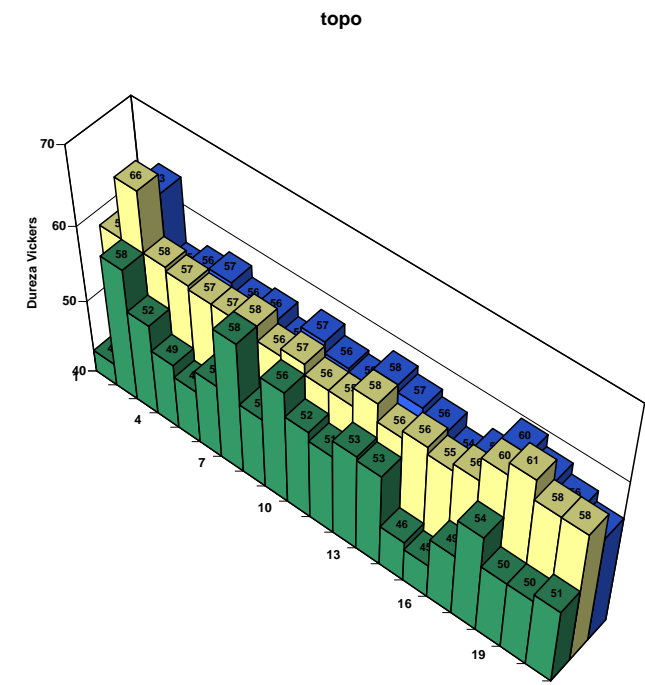

b)

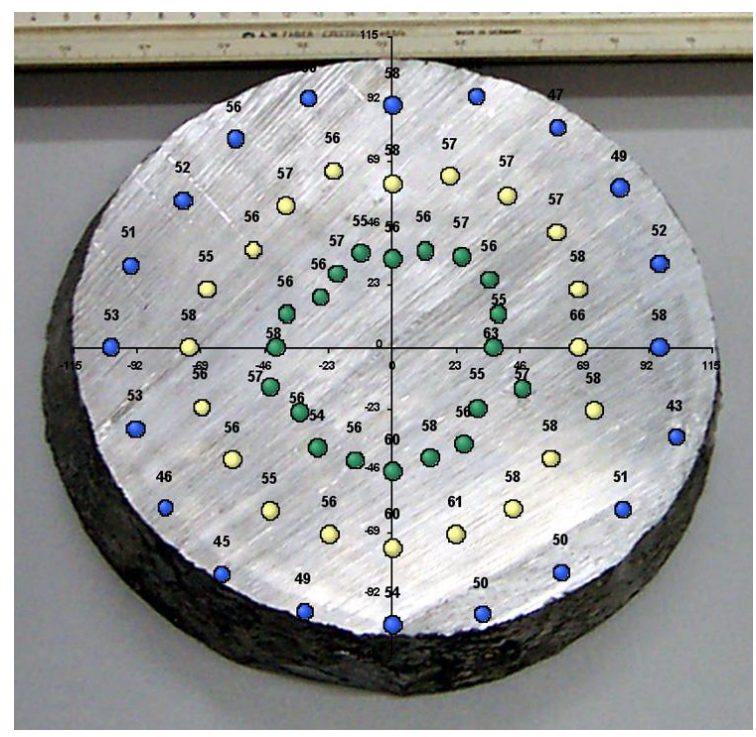

c)

Figura 11. a) Representação do perfil de dureza Vickers para o material do topo na condição como conformado por spray mostrando a variação radial de dureza (região da borda em azul, região do meio em amarelo e região do centro em verde. b) Gráfico de barras mostrando a evolução do perfil em linha para as regiões da borda em azul, região do meio em amarelo e região do centro em verde. c) Superposição do gráfico do perfil de dureza Vickers com a imagem da seção do preformado. 


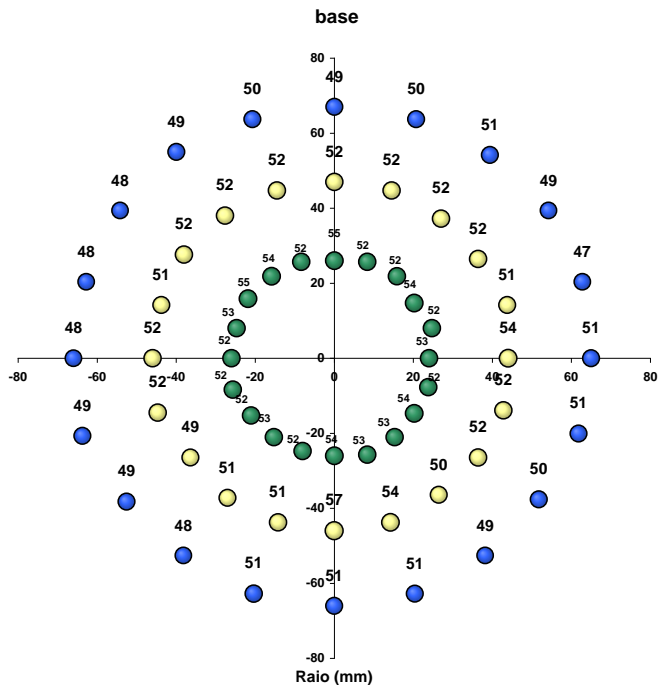

a)

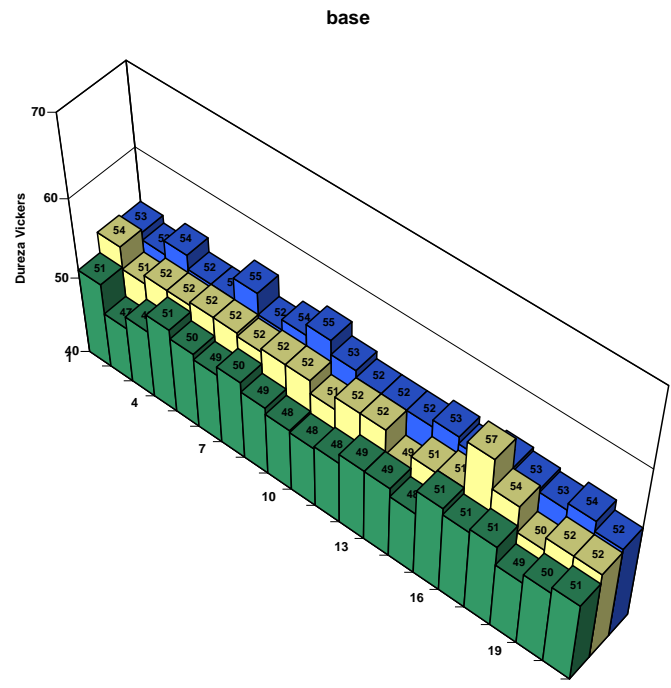

b)

Figura 12. a) Representação do perfil de dureza Vickers para o material da base na condição como conformado por spray mostrando a variação radial de dureza (região da borda em azul, região do meio em amarelo e região do centro em verde. b) Gráfico de barras mostrando a evolução do perfil em linha para as regiões da borda em azul, região do meio em amarelo e região do centro em verde.

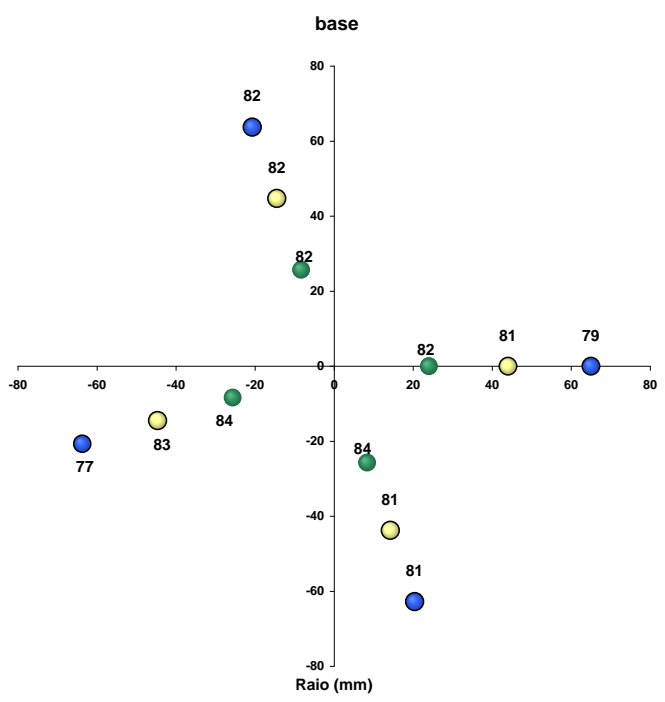

a)

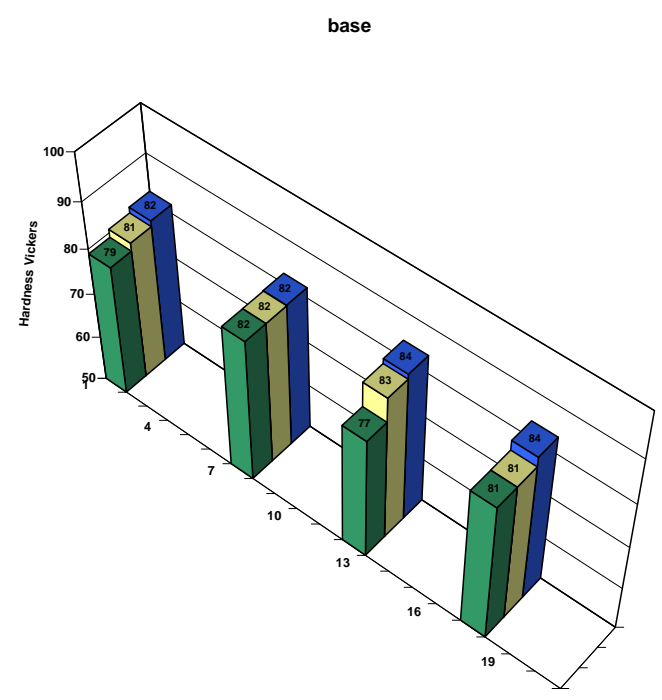

b)

Figura 13. a) Representação do perfil de dureza Vickers para o material da base na condição como conformado por spray mostrando a variação radial de dureza (região da borda em azul, região do meio em amarelo e região do centro em verde. b) Gráfico de barras mostrando a evolução do perfil em linha para as regiões da borda em azul, região do meio em amarelo e região do centro em verde. Tratamento térmico de $1 \mathrm{~h}$ de solubilização a $525^{\circ} \mathrm{C}$ sem envelhecimento. Lado base do preformado. 


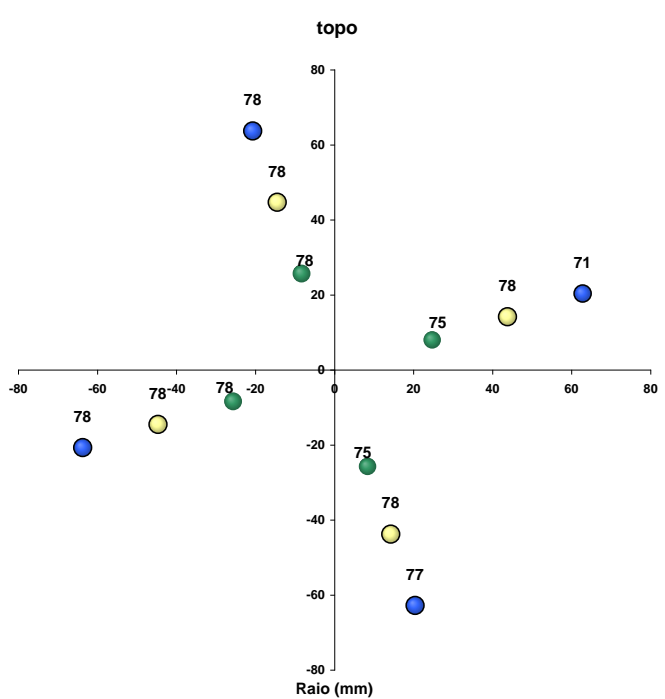

a)

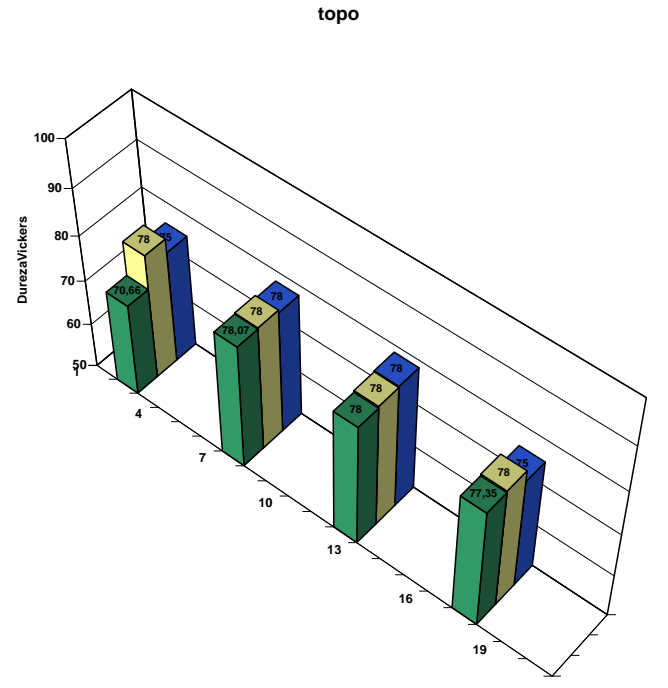

b)

Figura 14. a) Representação do perfil de dureza Vickers para o material do topo na condição como conformado por spray mostrando a variação radial de dureza (região da borda em azul, região do meio em amarelo e região do centro em verde. b) Gráfico de barras mostrando a evolução do perfil em linha para as regiões do topo em azul, região do meio em amarelo e região do centro em verde. Tratamento térmico de $1 \mathrm{~h}$ solubilização a $525^{\circ} \mathrm{C}$ sem envelhecimento. Lado topo do preformado.

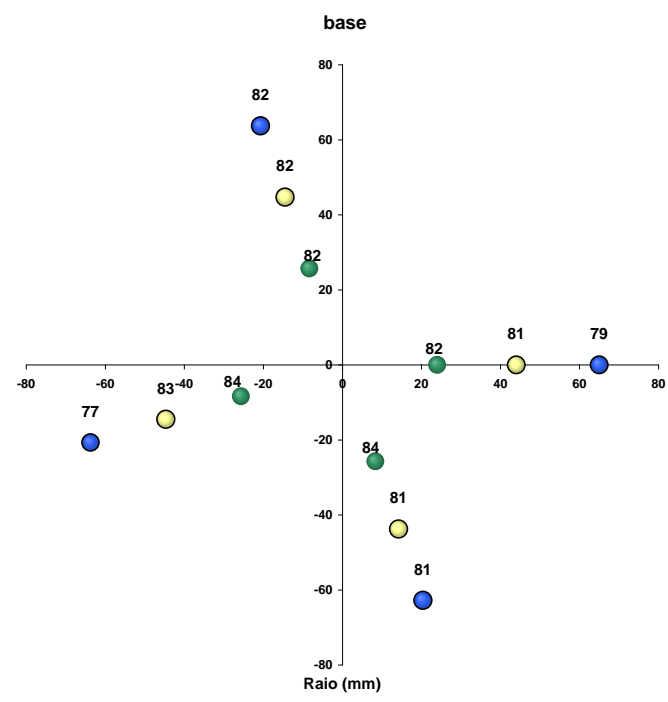

a)

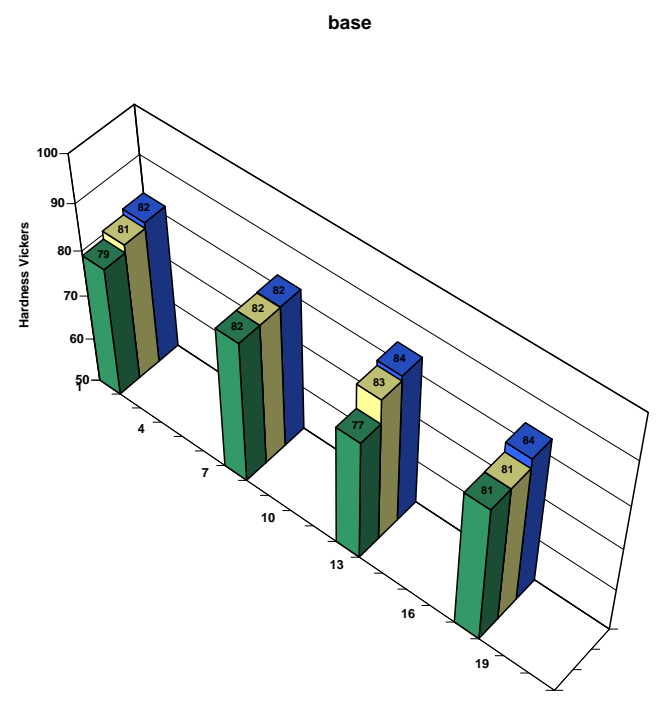

b)

Figura 15. a) Representação do perfil de dureza Vickers para o material da base na condição como conformado por spray mostrando a variação radial de dureza (região da borda em azul, região do meio em amarelo e região do centro em verde. b) Gráfico de barras mostrando a evolução do perfil em linha para as regiões da borda em azul, região do meio em amarelo e região do centro em ver de. Tratamento térmico de $1 \mathrm{~h}$ solubilização a $525{ }^{\circ} \mathrm{C}$ e $1 \mathrm{~h}$ de envelhecimento a $125^{\circ} \mathrm{C}$. Lado base do preformado. 


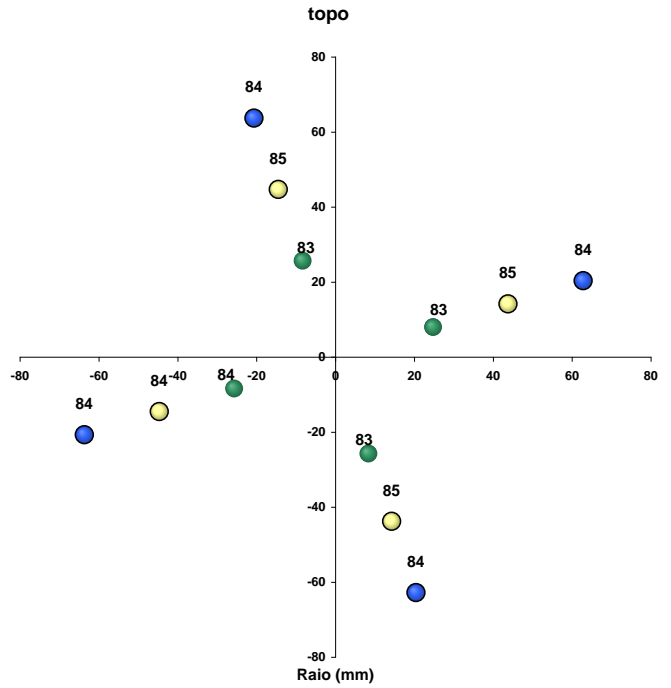

a)

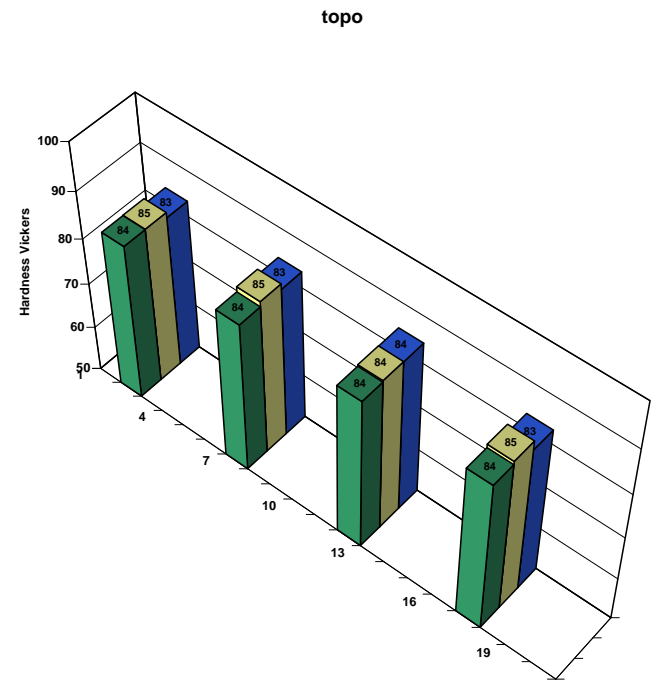

b)

Figura 16. a) Representação do perfil de dureza Vickers para o material do topo na condição como conformado por spray mostrando a variação radial de dureza (região da borda em azul, região do meio em amarelo e região do centro em verde. b) Gráfico de barras mostrando a evolução do perfil em linha para as regiões da borda em azul, região do meio em amarelo e região do centro em verde. Tratamento térmico de $1 \mathrm{~h}$ solubilização a $525^{\circ} \mathrm{C}$ e $1 \mathrm{~h}$ de envelhecimento a $125 \stackrel{\circ}{\circ}$. Lado topo do preformado.

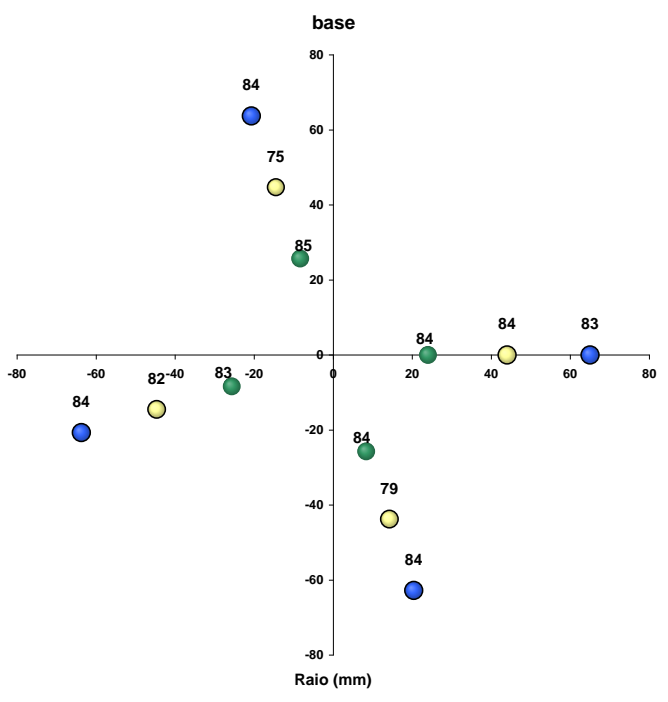

a)

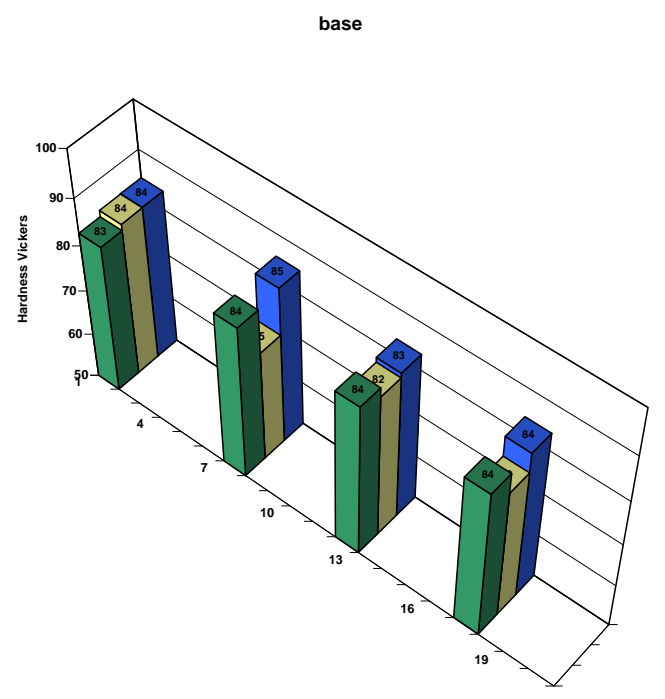

b)

Figura 17. a) Representação do perfil de dureza Vickers para o material da base na condição como conformado por spray mostrando a variação radial de dureza (região da borda em azul, região do meio em amarelo e região do centro em verde. b) Gráfico de barras mostrando a evolução do perfil em linha para as regiões da borda em azul, região do meio em amarelo e região do centro em verde.Tratamento térmico de $1 \mathrm{~h}$ solubilização a $525{ }^{\circ} \mathrm{C}$ e $10 \mathrm{~h}$ de envelhecimento a $125^{\circ} \mathrm{C}$. Lado base do preformado. 


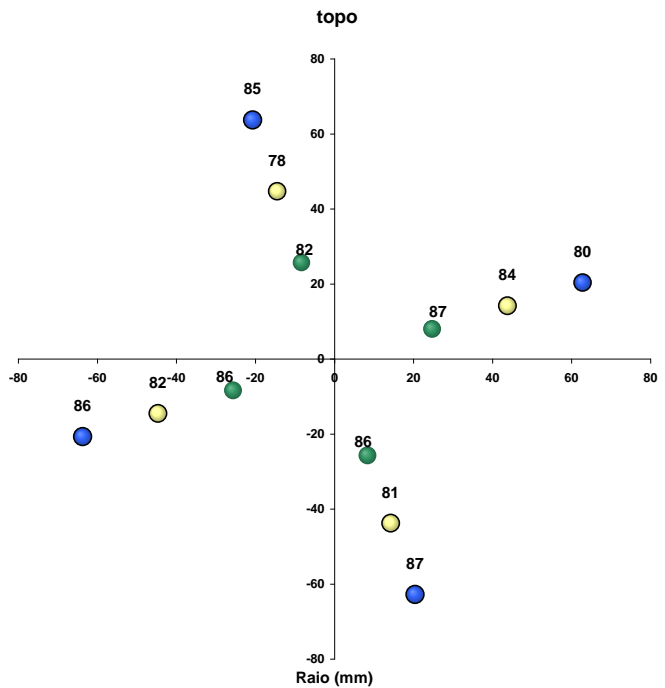

a)

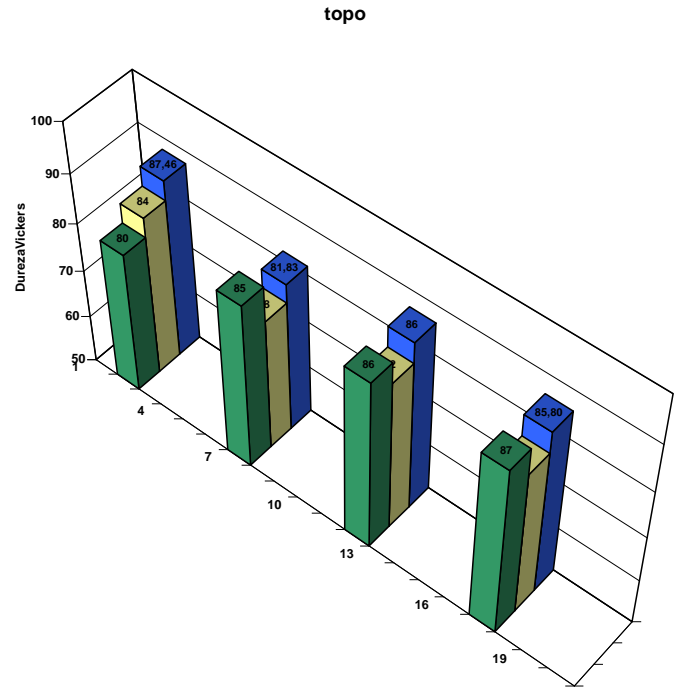

b)

Figura 18. a) Representação do perfil de dureza Vickers para o material do topo na condição como conformado por spray mostrando a variação radial de dureza (região da borda em azul, região do meio em amarelo e região do centro em verde. b) Gráfico de barras mostrando a evolução do perfil em linha para as regiões da borda em azul, região do meio em amarelo e região do centro em

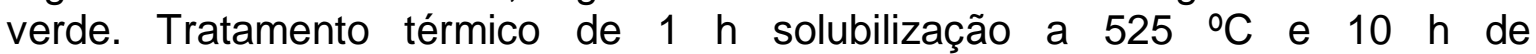
envelhecimento a $125^{\circ} \mathrm{C}$. Lado topo do preformado.

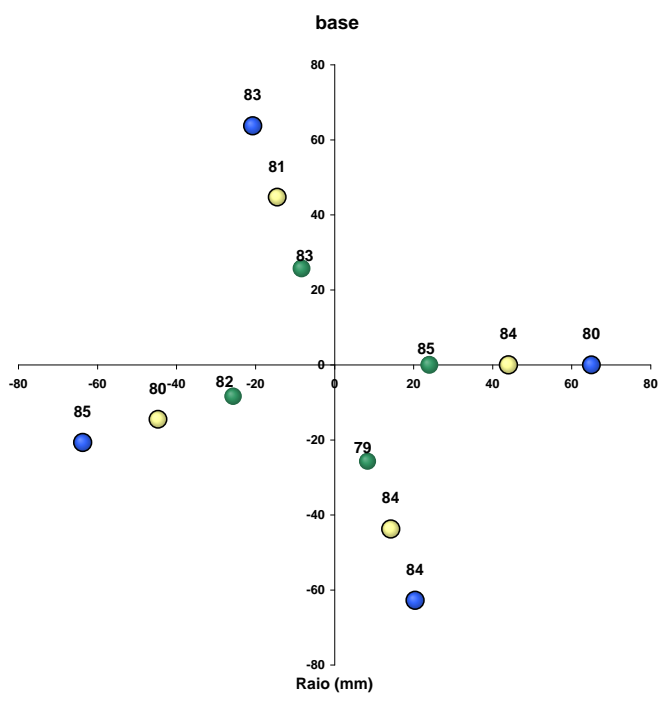

a)

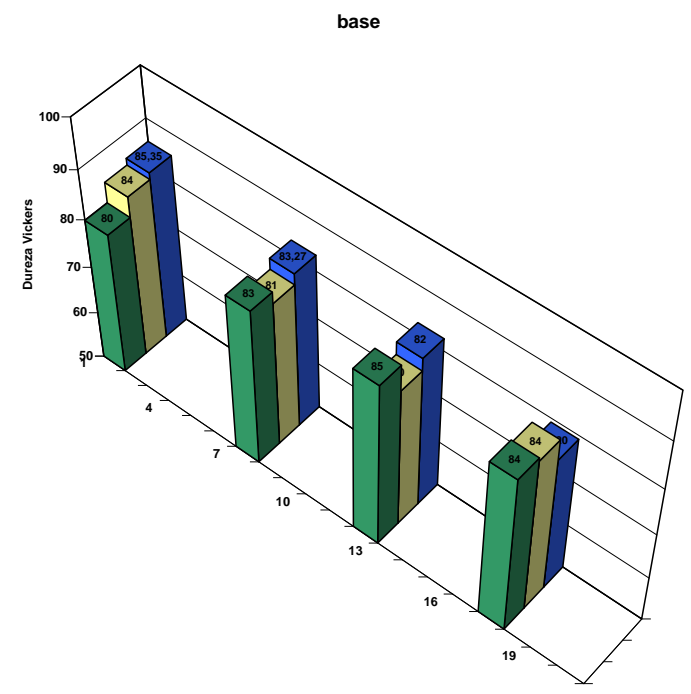

b)

Figura 19. a) Representação do perfil de dureza Vickers para o material da base na condição como conformado por spray mostrando a variação radial de dureza (região da borda em azul, região do meio em amarelo e região do centro em verde. b) Gráfico de barras mostrando a evolução do perfil em linha para as regiões da borda em azul, região do meio em amarelo e região do centro em verde. Tratamento térmico de $1 \mathrm{~h}$ solubilização a $525{ }^{\circ} \mathrm{C}$ e $100 \mathrm{~h}$ de envelhecimento a $125^{\circ} \mathrm{C}$. Lado base do preformado. 


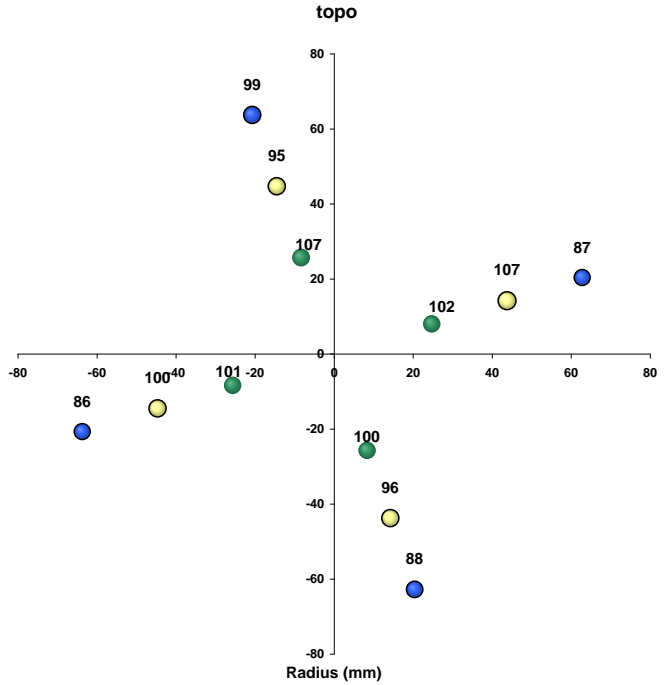

a)

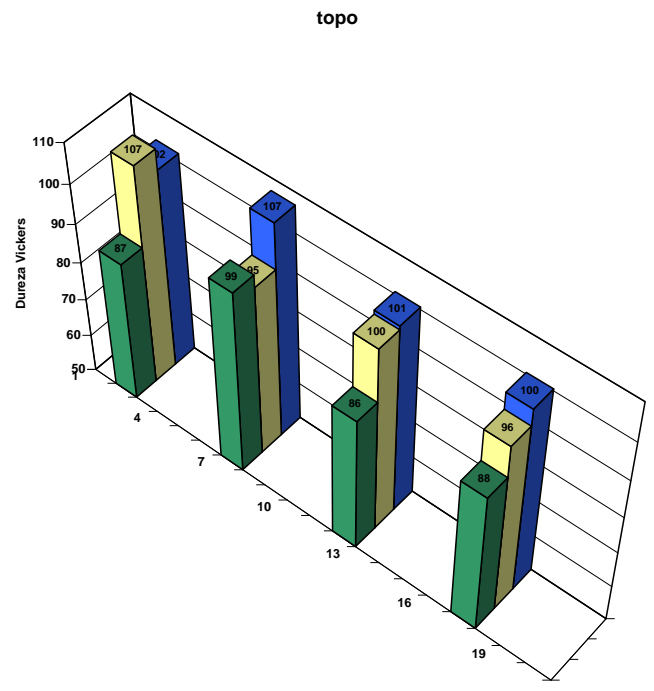

b)

Figura 20. Representação do perfil de dureza Vickers para o material do topo na condição como conformado por spray mostrando a variação radial de dureza (região da borda em azul, região do meio em amarelo e região do centro em verde. b) Gráfico de barras mostrando a evolução do perfil em linha para as regiões da borda em azul, região do meio em amarelo e região do centro em verde. Tratamento térmico de $1 \mathrm{~h}$ solubilização a $525{ }^{\circ} \mathrm{C}$ e $100 \mathrm{~h}$ de envelhecimento a $125^{\circ} \mathrm{C}$. Lado topo do preformado.

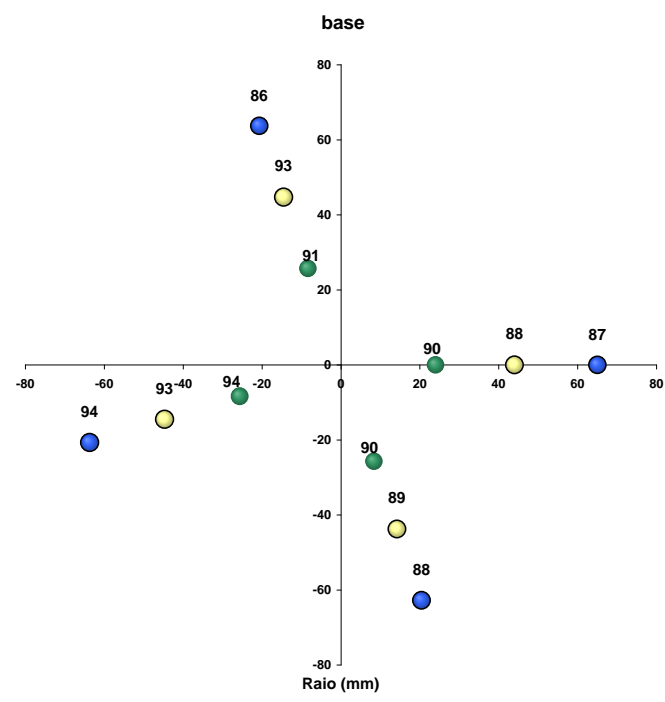

a)

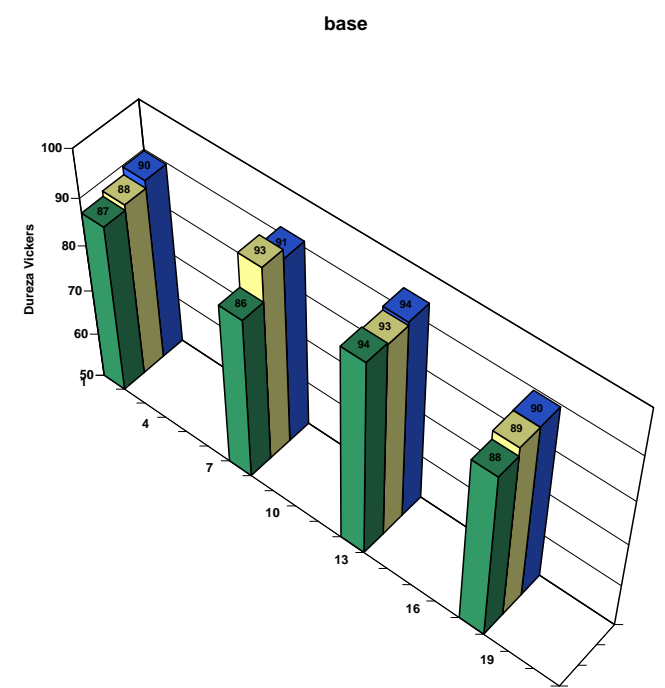

b)

Figura 21. a) Representação do perfil de dureza Vickers para o material da base na condição como conformado por spray mostrando a variação radial de dureza (região da borda em azul, região do meio em amarelo e região do centro em verde. b) Gráfico de barras mostrando a evolução do perfil em linha para as regiões da borda em azul, região do meio em amarelo e região do centro em verde. Tratamento térmico de $1 \mathrm{~h}$ solubilização a $525 \stackrel{\circ}{\circ} \mathrm{C}$ e $500 \mathrm{~h}$ de envelhecimento a $125 \stackrel{\circ}{ } \mathrm{C}$. Lado base do preformado. 


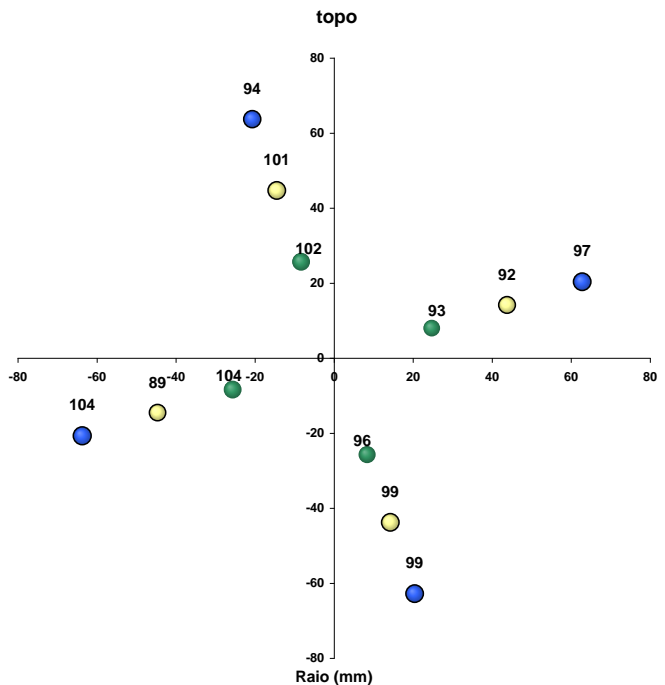

a)

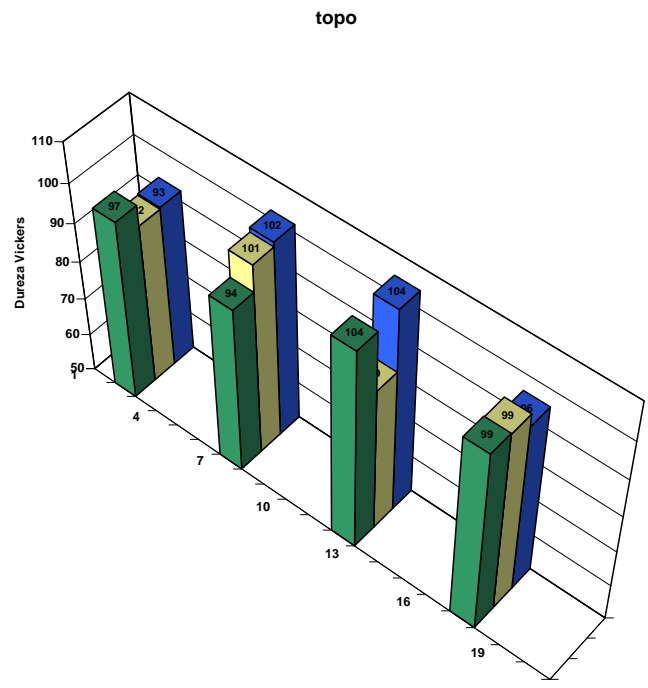

b)

Figura 22. a) Representação do perfil de dureza Vickers para o material do topo na condição como conformado por spray mostrando a variação radial de dureza (região da borda em azul, região do meio em amarelo e região do centro em verde. b) Gráfico de barras mostrando a evolução do perfil em linha para as regiões da borda em azul, região do meio em amarelo e região do centro em verde. Tratamento térmico de $1 \mathrm{~h}$ solubilização a $525{ }^{\circ} \mathrm{C}$ e $500 \mathrm{~h}$ de envelhecimento a $125^{\circ} \mathrm{C}$. Lado topo do preformado.

\subsection{Microscopia óptica}

Foi realizado a microscopia óptica $(\mathrm{MO})$ do material de partida, conformado por spray (preformado) e material solubilizado. Todas as amostras sofreram o ataque com ácido fluorídrico e álcool etílico.

Foram realizadas a análises por microscopia óptica nas amostras como recebido (material de partida), após a conformação por spray. Após este processo as amostras foram submetidas ao tratamento térmico de solubilização pelos intervalos de $1 \mathrm{~h}, 10 \mathrm{~h}, 100 \mathrm{~h}$ e $500 \mathrm{~h}$ na temperatura de $525^{\circ} \mathrm{C}$. Na análise do material de partida com aumento de 500 vezes observou-se a microestrutura de rede de intermetálicos de ferro e a matriz de alumínio.

A microestrutura da liga após a conformação por spray sem o tratamento térmico observou-se por $\mathrm{MO}$ com aumento de 500 vezes a microestrutura de refino e redução do tamanho dos grãos.

As microestruturas apresentam praticamente a mesma formação estrutural, 
matriz de fase alfa com grande quantidade de pequenos (finos) precipitados dispersos e intermetálicos ricos em ferro (fases mais grosseiras). Não há muita diferença entre essas microestruturas.

Há uma aparência na existência de porosidades (que nas fotos se confundem com precipitados). Os precipitados finos devem em sua essência, ser de $\mathrm{Mg}_{2} \mathrm{Si}$ já que são os principais elementos da liga.

Num processo de solubilização e envelhecimento, fases endurecedoras não ficam visíveis na microscopia óptica. Há um grande número de fases precipitadas nas estruturas tratadas. Existem áreas livres de precipitados provavelmente em contorno de grãos. Estas áreas podem representar problemas em relação à aplicação de tensões, pois, em relação a outras áreas (ricas nos precipitados) seriam menos resistentes, podendo ocorrer em relação á eventual ação por formas localizadas de corrosão galvânica.

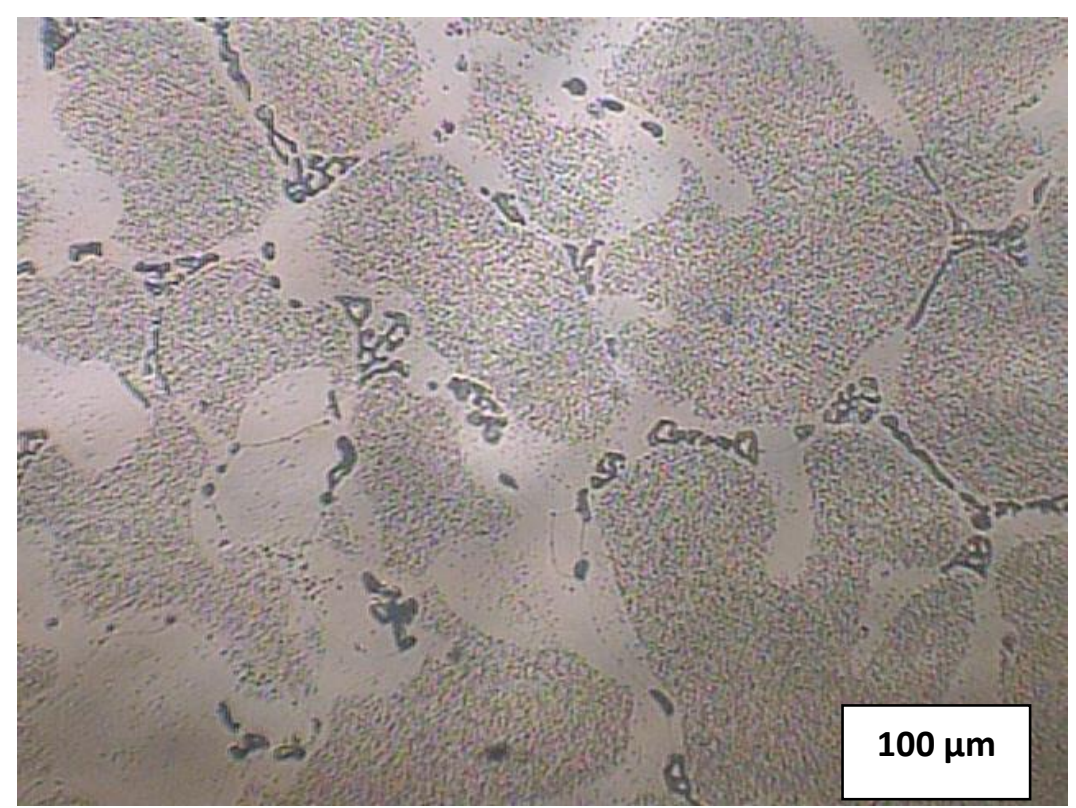

Figura 23. Material de partida. Matéria prima do processo antes da fusão para a conformação por spray. 


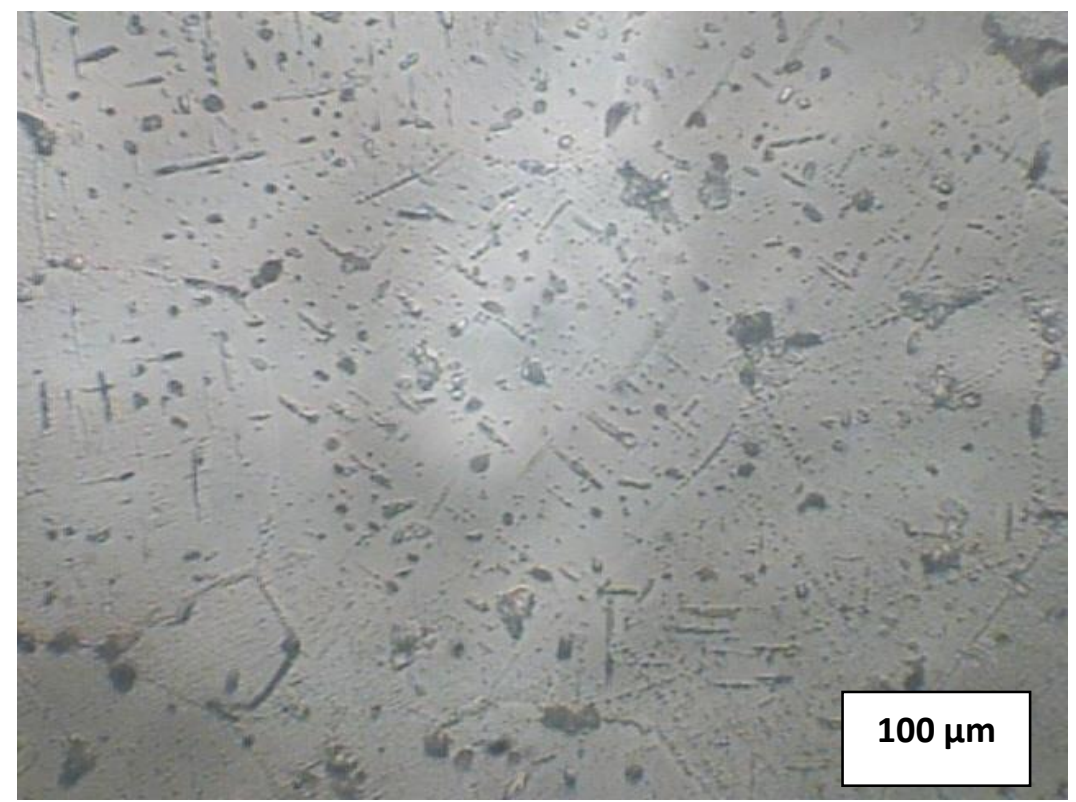

Figura 24. Material após realização do processo de conformação por spray, sem passar pelas fases do tratamento térmico. Lado base da preformado.

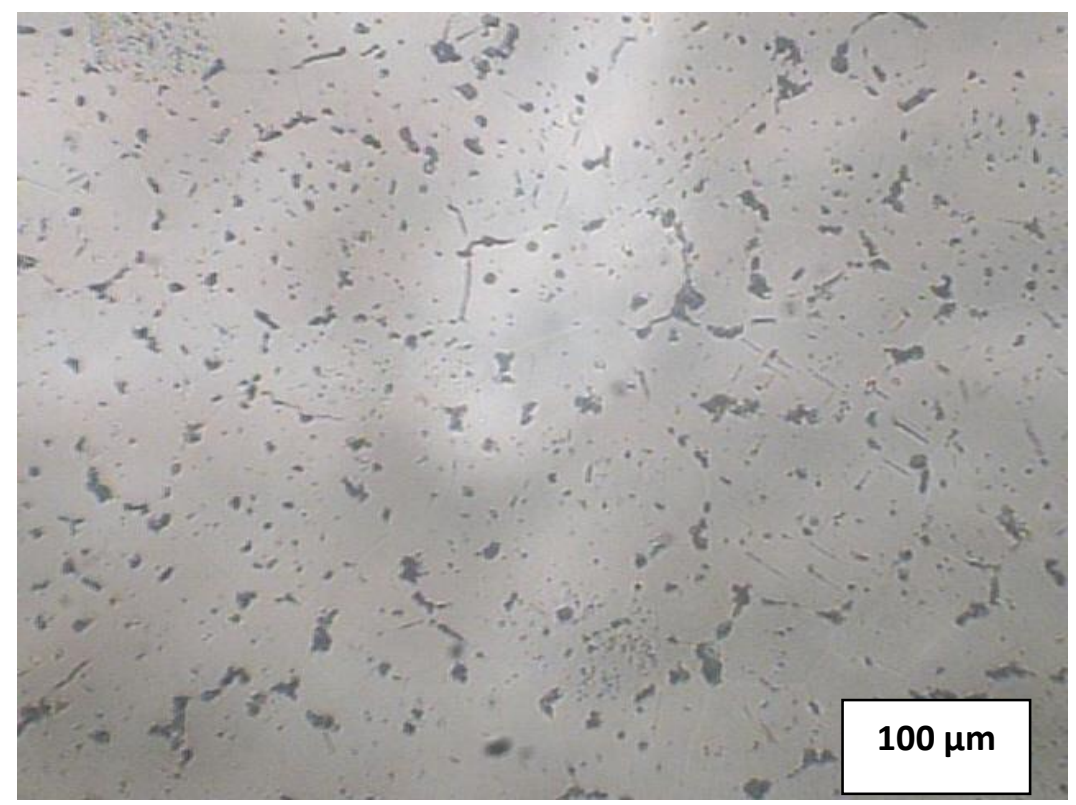

Figura 25. Material após realização do processo de conformação por spray, sem passar pelas fases do tratamento térmico. Lado topo da preformado. 


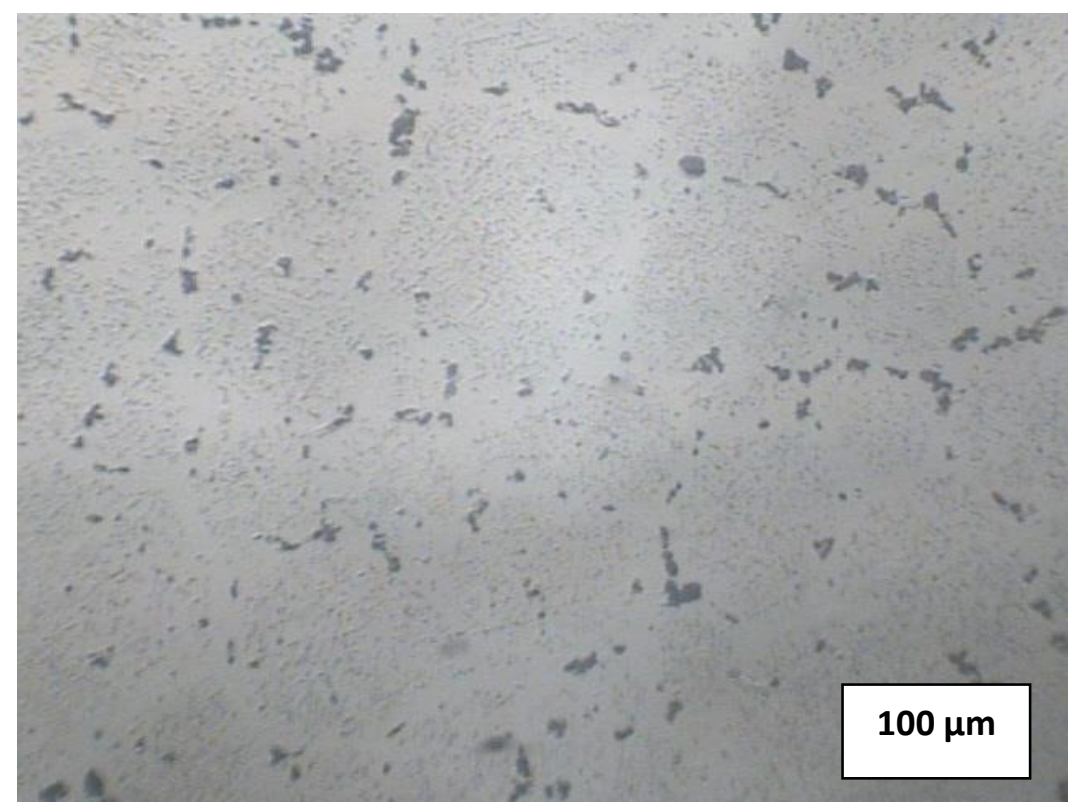

Figura 26. Material após realização do processo de conformação por spray. Tratamento térmico de $1 \mathrm{~h}$ de solubilização a $525{ }^{\circ} \mathrm{C}$ sem envelhecimento. Posição 7TC.

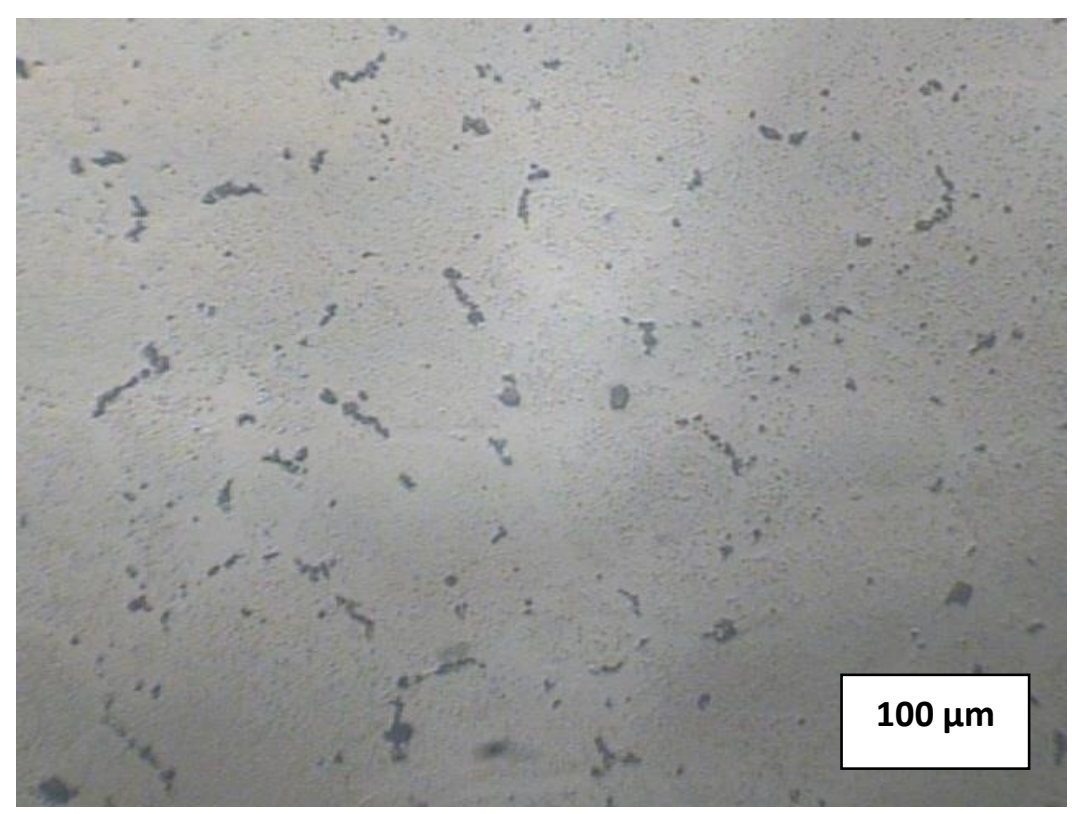

Figura 27. Material após realização do processo de conformação por spray. Tratamento térmico $1 \mathrm{~h}$ de solubilização a $525{ }^{\circ} \mathrm{C}$ sem envelhecimento. Posição $17 \mathrm{BC}$. 


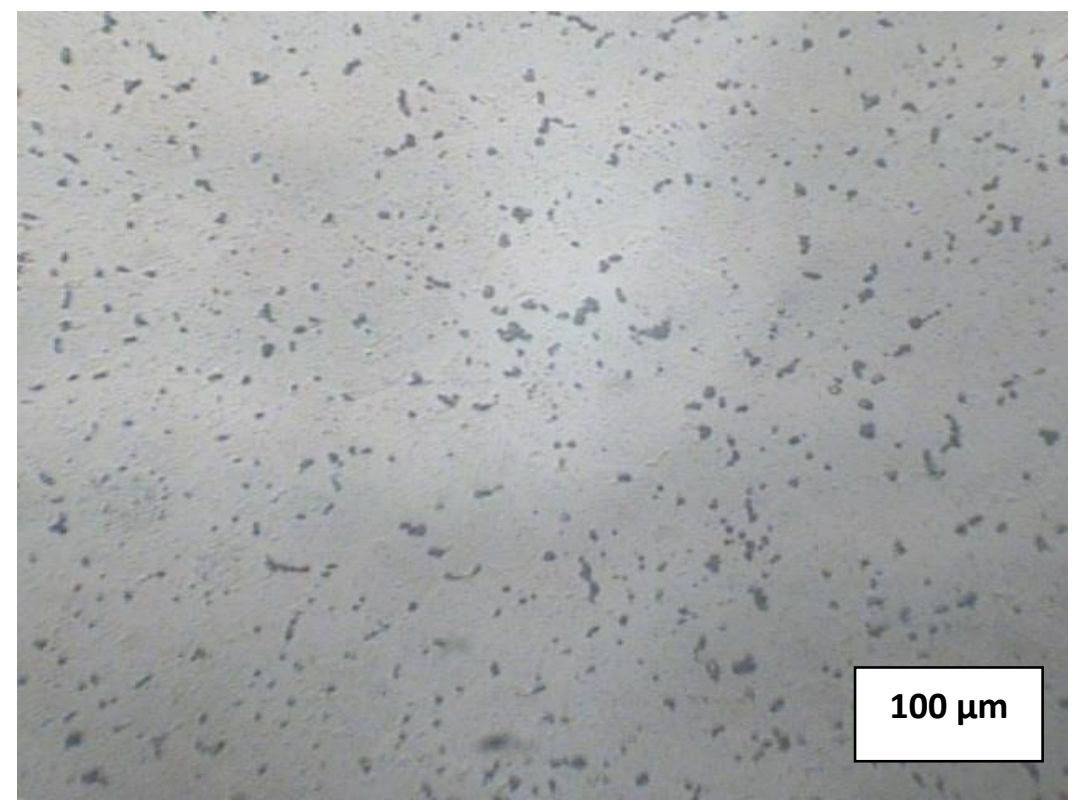

Figura 28. Material após realização do processo de conformação por spray. Tratamento térmico de $1 \mathrm{~h}$ de solubilização a $525^{\circ} \mathrm{C}$ e $1 \mathrm{~h}$ de envelhecimento a $125 \stackrel{\circ}{ } \mathrm{C}$.

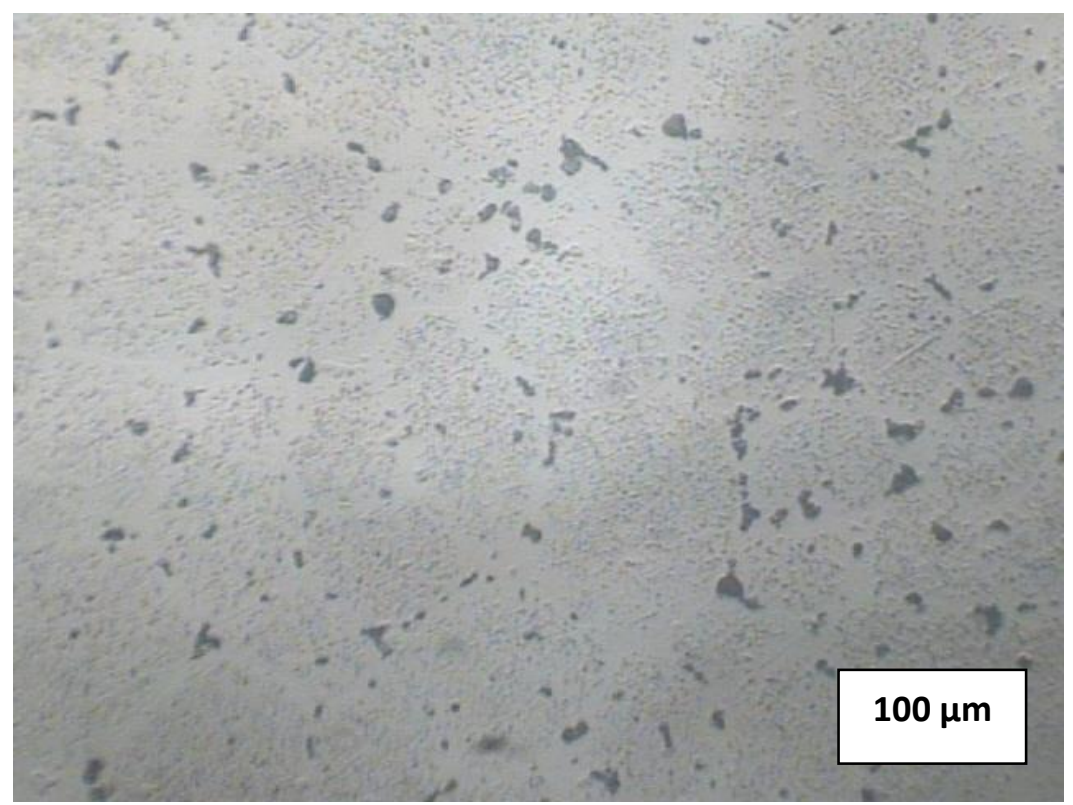

Figura 29. Material após realização do processo de conformação por spray. Tratamento térmico de $1 \mathrm{~h}$ de solubilização a $525^{\circ} \mathrm{C}$ e $10 \mathrm{~h}$ de envelhecimento a $125^{\circ} \mathrm{C}$. Posição $17 \mathrm{~TB}$. 


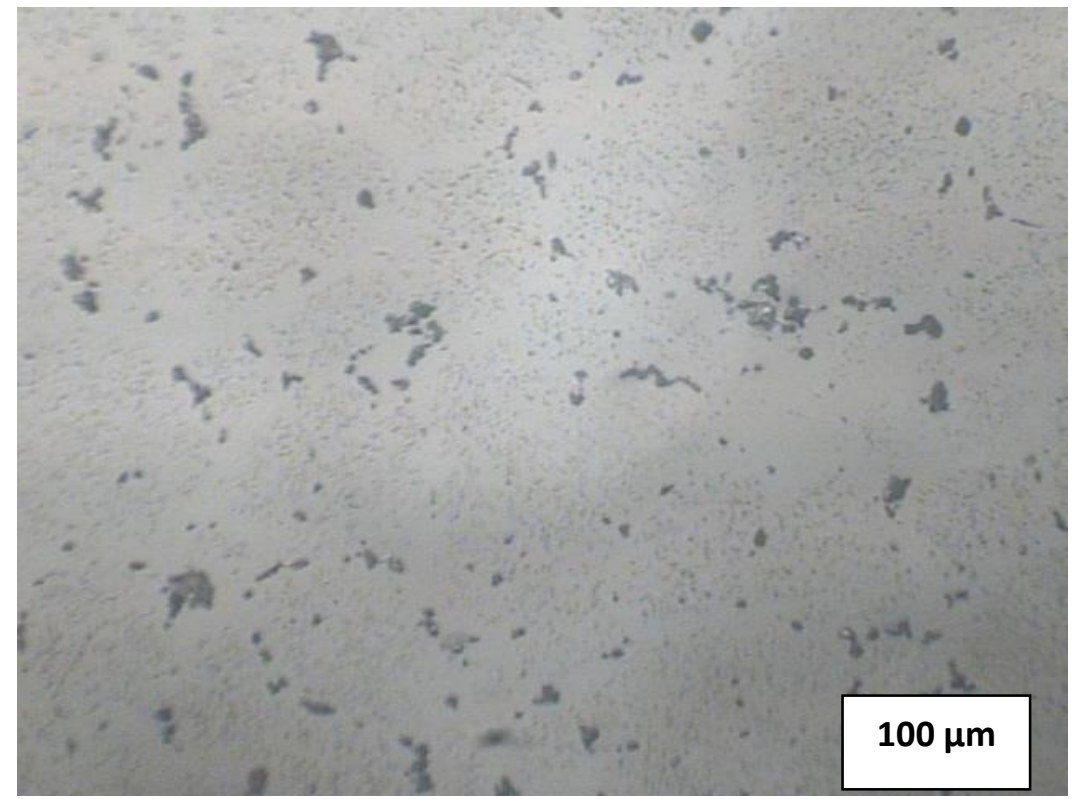

Figura 30. Material após realização do processo de conformação por spray. Tratamento térmico de $1 \mathrm{~h}$ de solubilização a $525^{\circ} \mathrm{C}$ e $10 \mathrm{~h}$ de envelhecimento a $125^{\circ} \mathrm{C}$. Lado topo preformado. Posição 7TM.

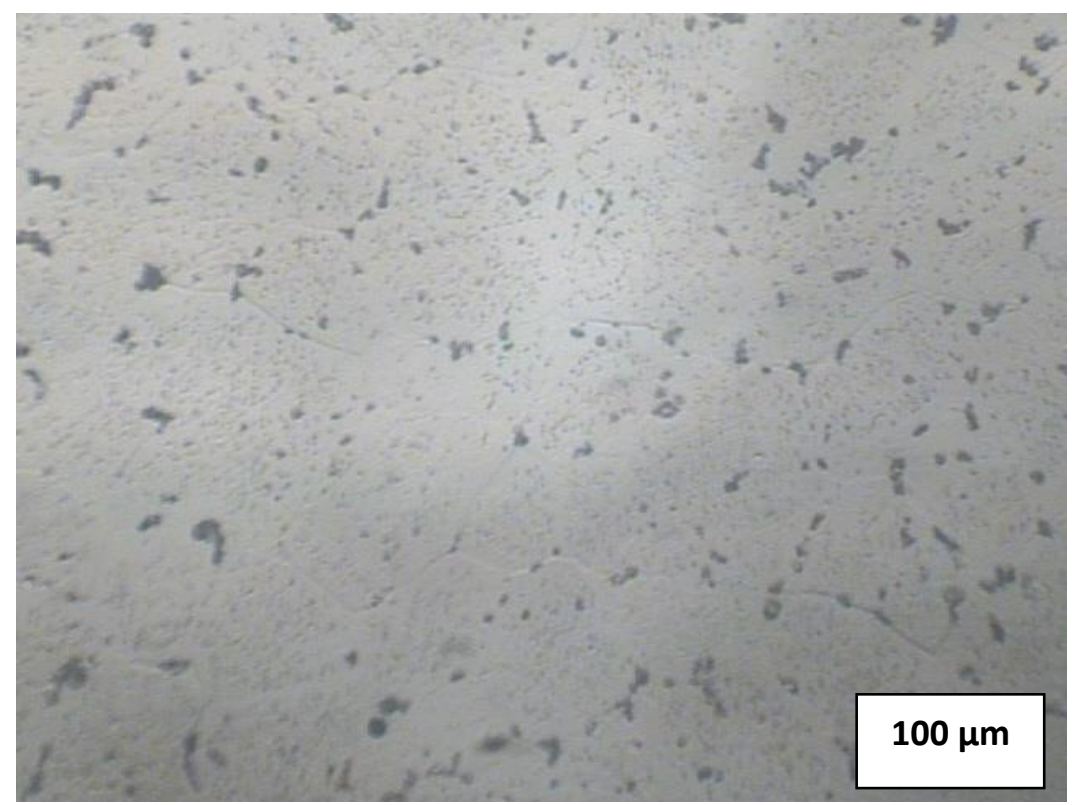

Figura 31. Material após realização do processo de conformação por spray. Tratamento térmico de $1 \mathrm{~h}$ de solubilização a $525^{\circ} \mathrm{C}$ e $100 \mathrm{~h}$ de envelhecimento a $125^{\circ} \mathrm{C}$. Posição 2BB. 


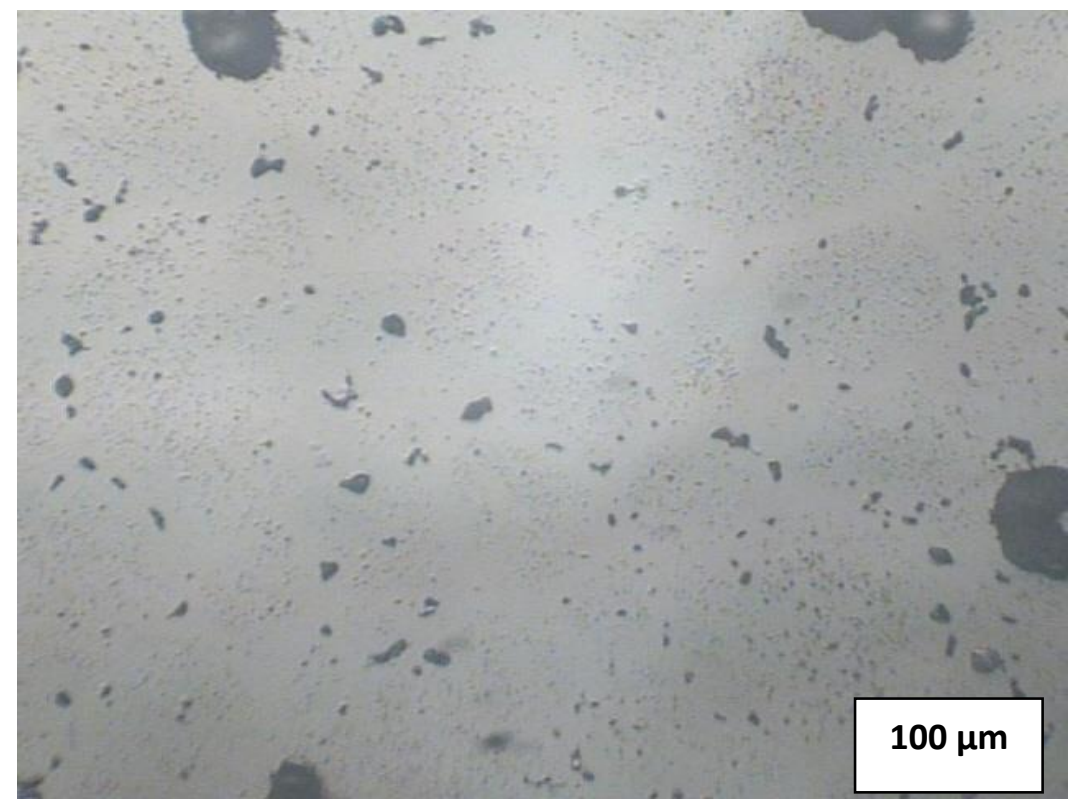

Figura 32. Material após realização do processo de conformação por spray. Tratamento térmico de $100 \mathrm{~h}$ de solubilização a $525{ }^{\circ} \mathrm{C}$ e $100 \mathrm{~h}$ de envelhecimento a $125^{\circ} \mathrm{C}$. Posição 2BB.

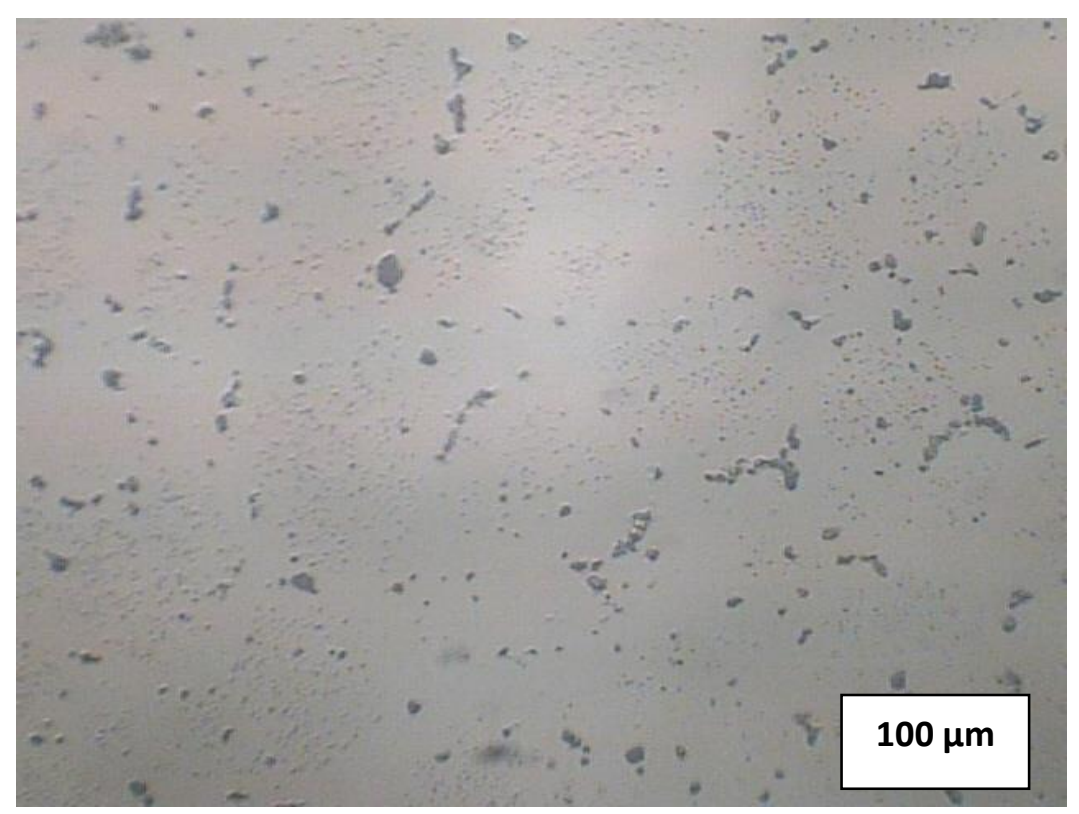

Figura 33. Material após realização do processo de conformação por spray. Tratamento térmico de $1 \mathrm{~h}$ de solubilização a $525{ }^{\circ} \mathrm{C}$ e $500 \mathrm{~h}$ de envelhecimento a $125^{\circ} \mathrm{C}$. Lado base da preformado. Posição 7BC. 


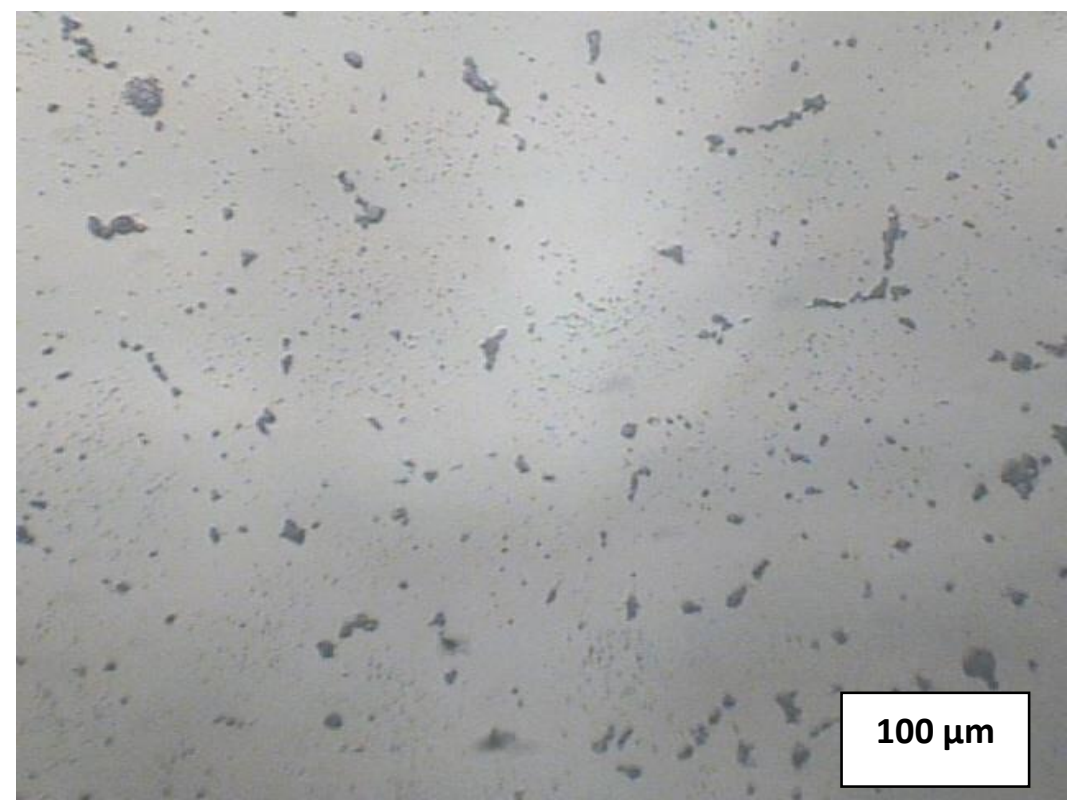

Figura 34. Material após realização do processo de conformação por spray. Tratamento térmico de $500 \mathrm{~h}$ de solubilização a $525{ }^{\circ} \mathrm{C}$ e $500 \mathrm{~h}$ de envelhecimento a $125^{\circ} \mathrm{C}$. Posição 8BM. 


\section{CONCLUSÕES}

Nos ensaios de dureza Vickers foram verificadas uma uniformidade de dureza no material em toda a extensão do preformado nas posições do lado topo e base, nos trechos da borda, meio e centro. No processo de obtenção do mesmo é gerenciado por um sistema computadorizado. Os resultados apresentados mantém-se de forma normal devido a poucas variações nos níveis de dureza Vickers.

$\mathrm{O}$ tratamento térmico de solubilização a $525{ }^{\circ} \mathrm{C}$ por $1 \mathrm{~h}$ foi suficiente para homogeneizar a microestrutura, além de aumentar a dureza causou uma melhor distribuição dos elementos de liga, principalmente mantidos em solução sólida mostrou menos por um perfil de dureza variável em relação ao núcleo, médio e região de borda do preformado.

Os tratamentos térmicos de envelhecimento de $1 \mathrm{~h}, 10 \mathrm{~h}, 100 \mathrm{~h}$ e $500 \mathrm{~h}$ mostraram que o material conformado por spray é muito estável em relação a variação de durezas. 


\section{TRABALHOS FUTUROS}

A microscopia eletrônica de varredura (MEV), quando comparada a microscopia óptica, apresenta maior resolução, além de possibilitar a observação de relevo em foco (profundidade). No MEV, os materiais serão caracterizados em termos da composição química das fases observáveis - por espectrometria de dispersão de energia (EDS).

As propriedades mecânicas serão avaliadas em termos de curvas de dureza. Adotar-se-á, neste trabalho, medidas de dureza Vickers após a solubilização na temperatura de $525^{\circ} \mathrm{C}$ nos períodos de $10 \mathrm{~h}, 100 \mathrm{~h}$ e $500 \mathrm{~h}$ com posterior envelhecimento na temperatura de $125^{\circ} \mathrm{C}$ em períodos de $1,10,100 \mathrm{e}$ 500 h com isso serão realizados os ensaios em questão. 


\section{REFERÊNCIAS BIBLIOGRÁFICAS}

[1] Fundamentos e Aplicações do Alumínio - ABAL- Associação Brasileira de Alumínio. Edição Maio/2007.

[2] SPIM, J. A., Tratamento Térmico do Alumínio e suas Ligas. Apostila do curso ABM - Associação Brasileira de Metalurgia e Materiais, Março/2007.

[3] CONSTANTINO, V. R. L.; ARAKI, K; SILVA, D.O.; OLIVEIRA,W. Preparação de compostos de alumínio a partir da bauxita: considerações sobre alguns aspectos envolvidos em um experimento didático. Química Nova, v.25, nำ, p.490498, 2002.

[4] WEINGAERTHER, W. L.; SCHROETER. R. B. Tecnologia de usinagem do alumínio e suas ligas, 2 ${ }^{\mathrm{a}}$ Ed., 1991.

[5] MATHERS, G. The Welding of Aluminium and its Alloys, Woodhead Publishing Limited, 1st Edition, 2002, Cambridge.

[6] Fundamentos e Aplicações do Alumínio - ABAL- Associação Brasileira de Alumino. Edição Maio/2007.

[7] BOLFARINI, C. I Workshop de Grupos de Pesquisa do DEMA Dezembro 2002-Solidificação e Fundição de Metais. http:/www.dema.ufscar.br/solfun.

Acessado em 09/09/2007.

[8] Jesus, E. R. B.; Tese de Doutorado na Universidade der São Paulo/ IPEN Instituto de Pesquisas Energéticas e Nucleares-: Ferramentas de Usinagem em Aço Rápido AISI M2 Obtido por Conformação por “Spray”(ANO).

[9] CABIBBO, M.; EVANGELISTA, E.; SPIGARELLI, S.; CERRI, E. Characterisation of a 6082 aluminium alloy after tixoforming INFM/ Departimento di Meccanica, University of Ancona, Italy, 2000.

[10] MYHR, O.R.; GRONG, O. Process Modeling Applied to 6082 - T6 Aluminium Weldments - Reactuo Kinetics, The Norwegian Institute of Technology, Norway, 1991.

[11] WIDLICKI, P.; GARBACZ, H.; LEWANDOWSKA, M.; PACHLA, W.;

KURZYDLOWSKI, K. J. Microstructure and Mechanical Properties of 6082 Aluminum Alloy Processed By Hydrostatic Extrusion, Warsaw University of technology, faculty of materials science and engineering, Woloska, Poland, 2006.

[12] GUBICZA, J.; KRÁLLICS, G.; SCHILLER, I.; MALGIN, D. Evolution of the microstructure of Al 6082 alloy during equal-channel angular pressing. Department of Solid State Physics, Hungary, 2005.

[13] Martins, N. C. E. Estudo do comportamento das ligas de alumínio 6061 e 6082. Departamento de Engenharia Cerâmica e do Vidro, Universidade de Aveiro, 2008.

[14] DEAN, W. A. Effects of alloying elements and impurities on properties. In: HATCH, J. E. (Ed.). Aluminum: properties and physical metallurgy. Metals Park, Ohio: ASM, 1990. ch. 6, 200-41.

[15] CHUMSKI, V. Estudo do comportamento das ligas de alumínio-magnésio AlMg 5083 e AIMg 5182, sob solicitação em fadiga axial. 2003. 110 f. Dissertação 
(mestrado em Engenharia Mecânica Projetos e Materiais) Faculdade de Engenharia do campus de Guaratinguetá, universidade Estadual Paulista, Guaratinguetá, 2003.

[16] LEATHAM, A. G.; ELIAS, L.; YAMAN, M.; ITAMI, T.; KAWASHIMA, Y.; BROOKS, P. J. S.; HUMMERT, K.; TYLER, D. E.; CHESKIS, P.; DALAL, R. P.; PRICHARD, P. D. Spray forming - commercialisation and applications. Proc. of P/M World Congress, San Francisco, USA, June 23-24, 1992. p. 66-76.

[17] SINGER, A.R. E. "Recent Developments in the Spray Forming of Metals", Int. J. of Powder Metallurgy and Powder Technology, p.219-234, July (1985).

[18] POLMEAR, I. J. Light alloys, Metallurgy of the light metals. $2^{\text {nd }}$ Ed. New York, Chapman and Hall, 1989. p. 95.

[19] ROSSI, J. L. Projeto de pesquisa: caracterização de ligas produzidas conformação por spray por. São Paulo, IPEN, 1995. p. 2-5.

[20] MÄCHLER, R. ET AL. Structure mechanical properties and stress corrosion behaviour of high strength spray deposited 7000 series aluminium alloy. Materials Science and Technology, v. 7, n. 5, May 1991. p. 447-51.

[21] ERUKHIMOVITCH, V.; BARAM, J. Critical study of the spray atomization and co-deposition process for the production of metal matrix composites. Proc. of the Powder Metallurgy World Congress. Paris, France, Les Editions de Physique, v.3, 1994. P. 1889-93.

[22] GOMES, E. G.; ROSSI, J. L.; AMBROZIO FILHO, F. Planta de conformação pro spray - Uma tecnologia disponível. 50ํㅡㄹ Congresso Anual da ABM, São Paulo, 1995. p. 161-71.

[23] LEATHAM, A. G. et al. The Osprey process an overview of the commercial developments for spray forming round billets in advanced ferrous and non-ferrous alloys. Cong. on Adv. Materials and Processing, Kyongju, Korea, 1995.

[24] ROSSI, J. L. Projeto de pesquisa: caracterização de ligas produzidas conformação por spray por. São Paulo, IPEN, 1995. p. 2-5.

[25] LEATHAM, A. G.; ROSSI, J. L. A exploração comercial do processo Osprey. M\&M Metalurgia \& Materiais, Caderno Técnico, vol. 53, n. 461, janeiro, 1997. p. 34-8.

[26] LEATHAM, A. G. Exploiting the metallurgical benefits of the Osprey process for commercial success. Materials World, Vol. 4, № 6, June 1996, p. 317-20. 